\title{
Short-term carbon input increases microbial nitrogen demand, but not microbial nitrogen mining, in a set of boreal forest soils
}

\author{
Birgit Wild $(\mathbb{D} \cdot$ Saeed Alaei $\cdot$ Per Bengtson · Samuel Bodé $\cdot$ Pascal Boeckx • \\ Jörg Schnecker • Werner Mayerhofer • Tobias Rütting
}

Received: 4 January 2017/ Accepted: 4 October 2017/Published online: 28 October 2017

(C) The Author(s) 2017. This article is an open access publication

\begin{abstract}
Rising carbon dioxide $\left(\mathrm{CO}_{2}\right)$ concentrations and temperatures are expected to stimulate plant productivity and ecosystem $\mathrm{C}$ sequestration, but these effects require a concurrent increase in $\mathrm{N}$ availability for plants. Plants might indirectly promote $\mathrm{N}$ availability as they release organic $\mathrm{C}$ into the soil (e.g., by root exudation) that can increase microbial soil organic matter (SOM) decomposition ("priming effect"), and possibly the enzymatic breakdown of $\mathrm{N}$-rich polymers, such as proteins, into bio-available units ("N mining"). We tested the adjustment of protein depolymerization to changing soil $\mathrm{C}$ and $\mathrm{N}$
\end{abstract}

Responsible Editor: Stephen D. Sebestyen.

Electronic supplementary material The online version of this article (doi:10.1007/s10533-017-0391-0) contains supplementary material, which is available to authorized users.

B. Wild $(\bowtie) \cdot$ T. Rütting

Department of Earth Sciences, University of Gothenburg, Gothenburg, Sweden

e-mail: birgit.wild@aces.su.se

B. Wild

Department of Environmental Science and Analytical Chemistry, Stockholm University, Stockholm, Sweden

B. Wild

Bolin Centre for Climate Research, Stockholm University, Stockholm, Sweden

S. Alaei · P. Bengtson

Department of Biology, Lund University, Lund, Sweden availability in a laboratory experiment. We added easily available $\mathrm{C}$ or $\mathrm{N}$ sources to six boreal forest soils, and determined soil organic $\mathrm{C}$ mineralization, gross protein depolymerization and gross ammonification rates (using ${ }^{15} \mathrm{~N}$ pool dilution assays), and potential extracellular enzyme activities after 1 week of incubation. Added $\mathrm{C}$ sources were ${ }^{13} \mathrm{C}$-labelled to distinguish substrate from soil derived $\mathrm{C}$ mineralization. Observed effects reflect short-term adaptations of non-symbiotic soil microorganisms to increased $\mathrm{C}$ or $\mathrm{N}$ availability. Although $\mathrm{C}$ input promoted microbial growth and $\mathrm{N}$ demand, we did not find indicators of increased $\mathrm{N}$ mobilization from SOM polymers, given that none of the soils showed a significant increase in protein depolymerization, and only one soil showed a significant increase in N-targeting enzymes. Instead, our findings suggest that microorganisms immobilized

\footnotetext{
S. Bodé · P. Boeckx

Isotope Bioscience Laboratory, Ghent University, Ghent, Belgium

J. Schnecker · W. Mayerhofer

Department of Microbiology and Ecosystem Science,

University of Vienna, Vienna, Austria

J. Schnecker

Department of Natural Resources and the Environment, University of New Hampshire, Durham, NH, USA
} 
the already available $\mathrm{N}$ more efficiently, as indicated by decreased ammonification and inorganic $\mathrm{N}$ concentrations. Likewise, although $\mathrm{N}$ input stimulated ammonification, we found no significant effect on protein depolymerization. Although our findings do not rule out in general that higher plant-soil $\mathrm{C}$ allocation can promote microbial $\mathrm{N}$ mining, they suggest that such an effect can be counteracted, at least in the short term, by increased microbial $\mathrm{N}$ immobilization, further aggravating plant $\mathrm{N}$ limitation.

Keywords Boreal forest · Priming - Microbial N mining · Organic $\mathrm{N} \cdot$ Protein depolymerization $\cdot \mathrm{N}$ mineralization $\cdot$ Ammonification

\section{Introduction}

Plant primary production in temperate, boreal, and arctic ecosystems is often limited by low soil $\mathrm{N}$ availability (Vitousek and Howarth 1991). Most soil N is contained within SOM polymers that are too large for immediate uptake by plants or microorganisms, and soil $\mathrm{N}$ availability consequently depends on the breakdown of these polymers into smaller units (Schimel and Bennett 2004). This process is catalyzed by extracellular enzymes that are released into the soil by microbial decomposers. Given that proteins alone represent ca. $40 \%$ of the soil $\mathrm{N}$ pool (Schulten and Schnitzer 1998), the depolymerization of proteins into oligopeptides and amino acids is thought to dominate the production of available $\mathrm{N}$ (Jan et al. 2009). Microorganisms take up available $\mathrm{N}$ and invest it in growth and enzyme synthesis, and only $\mathrm{N}$ in excess is released to the soil solution as ammonium (Schimel and Bennett 2004). This process is referred to as "ammonification" or, more generally, as " $\mathrm{N}$ mineralization", when other mineral $\mathrm{N}$ forms are considered.

Plants compete with soil microorganisms for available $\mathrm{N}$ forms (e.g., oligopeptides, amino acids, quarternary ammonium compounds, ammonium, nitrate), but might also be able to stimulate their mobilization from SOM. Plant roots release organic compounds into the soil, e.g., via root litter and root exudation (e.g., Jones et al. 2009; Rovira 1969), and thereby increase $\mathrm{C}$ availability in their vicinity. Increased $\mathrm{C}$ availability can promote the activity of microbial decomposers and facilitate SOM decomposition ("priming effect"; Kuzyakov et al. 2000), and thus accelerate not only the mineralization of soil organic $\mathrm{C}$ (SOC) to $\mathrm{CO}_{2}$, but possibly the release of available $\mathrm{N}$ from SOM. Additionally, plant-derived organic compounds typically have a low $\mathrm{N}$ content (e.g., sugars and organic acids; Jones et al. 2009), and it has been hypothesized that these compounds specifically promote the microbial synthesis of extracellular enzymes that target N-rich SOM polymers ("microbial N mining"; Craine et al. 2007). The release of organic $\mathrm{C}$ by plants into the soil might therefore not only stimulate SOC mineralization, but also soil $\mathrm{N}$ availability, facilitating plant primary production and, overall, ecosystem $\mathrm{C}$ sequestration.

Periods of increased $\mathrm{C}$ availability in the soil occur on timescales from hours to years, depending on the degradability and frequency of C inputs ("hot moments"; Kuzyakov and Blagodatskaya 2015). Root litter decomposition for instance increases $\mathrm{C}$ availability in the surrounding soil for months or even years (Kuzyakov and Blagodatskaya 2015). Root hairs, in contrast, have a life span of a few days (Kuzyakov and $\mathrm{Xu}$ 2013) where root exudation (e.g., of glucose) and plant $\mathrm{N}$ uptake alter $\mathrm{C}$ and $\mathrm{N}$ availability in their vicinity. Even on such short time frames, priming effects (Garcia-Pausas and Paterson 2011; Koranda et al. 2013; Wild et al. 2014), as well as changes in $\mathrm{N}$-targeting enzyme activities (Geisseler and Horwath 2009; Koranda et al. 2013) and gross N mineralization rates (Koranda et al. 2013; Landi et al. 2006; Murphy et al. 2015) with $\mathrm{C}$ addition have been frequently observed. While these findings suggest that even short-term changes in $\mathrm{C}$ availability can induce adaptations of microbial communities that alter SOM decomposition, and thereby $\mathrm{N}$ mining, major knowledge gaps remain. The studies cited above include observations of positive, negative and neutral effects of $\mathrm{C}$ addition on $\mathrm{N}$-targeting enzymes and gross $\mathrm{N}$ mineralization rates, which suggests that the direction and magnitude of the effects depend on initial soil properties such as $\mathrm{N}$ availability (Yin et al. 2016). Furthermore, direct evidence linking increases in $\mathrm{N}$-targeting enzyme activities and $\mathrm{N}$ mineralization rates to an accelerated breakdown of $\mathrm{N}$-containing SOM polymers is missing. Methods for quantifying gross production rates of oligopeptides or amino sugars by polymer breakdown are lacking, and although a method for gross production rates of amino 
acids is available (Wanek et al. 2010), it has rarely been applied. We are not aware of any study showing an adjustment of gross amino acid production by protein depolymerization to soil $\mathrm{C}$ or $\mathrm{N}$ availability. Considering the frequent $\mathrm{N}$ limitation of terrestrial plant productivity and consequently ecosystem $\mathrm{C}$ storage, a better mechanistic understanding of how plant-soil $\mathrm{C}$ allocation influences the breakdown of $\mathrm{N}$-containing SOM polymers such as proteins is urgently required.

In this study, we focus on short-term increases of $\mathrm{C}$ and $\mathrm{N}$ availability in soils and provide insights into their effects on gross release rates of amino acids from SOM proteins. We hypothesized that an increase in $\mathrm{C}$ availability would facilitate the microbial investment in extracellular enzymes that target $\mathrm{N}$-rich SOM polymers and thus promote protein depolymerization, overall leading to higher soil $\mathrm{N}$ availability, but also a higher mineralization of SOC to $\mathrm{CO}_{2}$. We expected that an increase in $\mathrm{N}$ availability would have the opposite effect, and reduce N-targeting enzyme activities and gross protein depolymerization rates. By affecting amino acid and ammonium production rates, these microbial adaptation mechanisms can alter soil $\mathrm{N}$ availability for plants. We further hypothesized that the magnitude of the response to $\mathrm{C}$ or $\mathrm{N}$ addition would depend on the initial balance between $\mathrm{C}$ and $\mathrm{N}$ availability in the soil, with strongest $\mathrm{C}$ effects where $\mathrm{C}$ availability was low, and strongest $\mathrm{N}$ effects where $\mathrm{N}$ availability was low. To describe the balance between $\mathrm{C}$ and $\mathrm{N}$ availability, we used the $\mathrm{C} / \mathrm{N}$ ratio of $\mathrm{SOM}$ as an indicator. Although $\mathrm{C}$ and $\mathrm{N}$ within SOM might differ in their chemical and physical stabilization, $\mathrm{C} / \mathrm{N}$ ratios of SOM have been found to be well correlated with indices of microbial $\mathrm{C}$ or $\mathrm{N}$ excess in soils (e.g., Mooshammer et al. 2014a; Spohn and Chodak 2015).

We tested our hypotheses in boreal forest soils where such effects are thought to be particularly pronounced (e.g., Fan et al. 2013; Hartley et al. 2012). Low $\mathrm{N}$ availability typically limits net primary production in this biome (LeBauer and Treseder 2008) and organic $\mathrm{N}$ forms likely dominate plant $\mathrm{N}$ uptake (Inselsbacher and Näsholm 2012). Given the mechanistic focus of our study, we tested our hypotheses in a laboratory incubation experiment, by manipulating $\mathrm{C}$ and $\mathrm{N}$ availability in six types of boreal forest soils that covered a range of SOM contents and decomposition states. We altered soil C or $\mathrm{N}$ availability by adding immediately available forms of $\mathrm{C}$ (glucose) or $\mathrm{N}$ (ammonium), monitored the release of $\mathrm{CO}_{2}$ from the soil over the course of 1 week, and in the case of glucose, distinguished between $\mathrm{CO}_{2}$ derived from added glucose (that was enriched in ${ }^{13} \mathrm{C}$ ) and from native SOC (that was of natural ${ }^{13} \mathrm{C}$ abundance). At the end of the incubation, we determined gross rates of protein depolymerization (the breakdown of proteins into amino acids) and ammonification (the microbial release of excess $\mathrm{N}$ as ammonium) using a set of ${ }^{15} \mathrm{~N}$ pool dilution assays, as well as extractable soil $\mathrm{C}$ and $\mathrm{N}$ pools, microbial biomass, and potential activities of a range of extracellular enzymes involved in the breakdown of different $\mathrm{C}$ - and $\mathrm{N}$-rich SOM polymers. Observed effects reflect physiological responses of non-symbiotic soil microorganisms to short-term increases in $\mathrm{C}$ or $\mathrm{N}$ availability.

\section{Materials and methods}

Soil sampling

We compared six types of boreal forest soils that we collected at two stations of the Swedish Infrastructure for Ecosystem Science (SITES), Svartberget in northern Sweden $\left(64^{\circ} 15^{\prime} \mathrm{N}, 19^{\circ} 47^{\prime} \mathrm{E}\right)$ and Skogaryd in south-western Sweden $\left(58^{\circ} 23^{\prime} \mathrm{N}, 12^{\circ} 09^{\prime} \mathrm{E}\right)$. Mean annual temperature and precipitation between 1981 and 2010 were $1.8^{\circ} \mathrm{C}, 614 \mathrm{~mm}$ in Svartberget (Laudon et al. 2013), and $6.8{ }^{\circ} \mathrm{C}, 803 \mathrm{~mm}$ in the vicinity of Skogaryd (Vänersborg meteorological station of the Swedish Meteorological and Hydrological Institute). These managed forests are typical for the boreal forest biome. They are dominated by Pinus sylvestris and Picea abies with an understory of Vaccinium myrtillus and Vaccinium vitis-idaea, and underlain by a patchwork of Podzols and Histosols (following the World Reference Base for Soil Resources classification; IUSS Working Group WRB 2007), with the latter at locations where fens or bogs had been drained and afforested.

Soils were sampled in November 2014 (Svartberget) and December 2014 (Skogaryd) before they started to freeze. We sampled both Histosols and Podzols at each site, and in the case of the Podzols, from both organic layers and mineral B horizons. Histosol samples were from a depth of $0-10 \mathrm{~cm}$, Podzol organic layer samples from 0 to $10 \mathrm{~cm}$, and 
Podzol mineral B horizon samples from 15 to $30 \mathrm{~cm}$. Skogaryd Histosol and Podzol organic layer samples were cut from the surface, the other soil samples were retrieved by coring. Each of the six soil categories (3 soil types $\times 2$ sites) was sampled in five replicates, with 5-10 $\mathrm{m}$ distance between individual sampling points. Overall, we thus retrieved 30 soil samples that covered a natural range in SOM quantity and quality, including $\mathrm{C} / \mathrm{N}$ ratios (Table 1 ). Immediately after sampling, we removed large roots from samples of Histosols and Podzol organic layers and homogenized the samples by hand. Podzol mineral horizons were sieved to $2 \mathrm{~mm}$. None of the sampled soils contained carbonates. Soil organic $\mathrm{C}$ and total $\mathrm{N}$ content, as well as $\mathrm{C}$ and $\mathrm{N}$ isotopic composition were measured in dried and ground samples using elemental analysisisotope ratio mass spectrometry (EA-IRMS; CE Instrument EA 1110 elemental analyzer, Finnigan MAT ConFlo II Interface, Finnigan MAT DeltaPlus IRMS), and $\mathrm{C} / \mathrm{N}$ ratios were calculated as mass ratios. Data are presented in Table 1. Samples were stored for a maximum of 7 weeks at $4{ }^{\circ} \mathrm{C}$ before the start of the experiment.

Since the aim of our study was not to describe gross protein depolymerization and ammonification rates in situ, but to investigate the microbial adjustment of these processes to changes in $\mathrm{C}$ and $\mathrm{N}$ availability, we opted for an experimental design that permitted us to control soil $\mathrm{C}$ and $\mathrm{N}$ availability, reduce variability in abiotic experimental conditions, and dissect mechanisms behind observed patterns. It should, however, be noted that the absence of plant roots leads to an underrepresentation of root associated microorganisms such as mycorrhiza that might contribute to protein depolymerization in situ (Read and PerezMoreno 2003). Furthermore, sample storage before incubation might have promoted the accumulation of inorganic $\mathrm{N}$ especially in the N-rich Skogaryd samples, as indicated by higher dissolved inorganic $\mathrm{N}$ concentrations in our control samples than in fresh soils (personal communication, T. Rütting). While these limitations mean that the presented data should not be interpreted as absolute concentrations and process rates that might be observed in the field, they do not constrain our ability to test our hypotheses related to relative effects of $\mathrm{C}$ and $\mathrm{N}$ addition on microbial processes and their dependency on the initial balance between $\mathrm{C}$ and $\mathrm{N}$ availability in the soil.
Setup of the incubation experiment and respiration measurements

We subjected the field-moist soils to three treatments by either amending them with immediately available $\mathrm{C}$ or $\mathrm{N}$ sources (glucose or ammonium), or leaving them unamended as controls. Before the start of the experiment, triplicates of fresh soil were weighed into flasks (60 $\mathrm{g}$ of Histosols and Podzol organic layers, $75 \mathrm{~g}$ of Podzol mineral horizons) that were then covered with parafilm and pre-incubated at room temperature $\left(19^{\circ} \mathrm{C}\right)$. Total volumes of the flasks were $305 \mathrm{ml}$, and the headspaces ranged between 225 and $271 \mathrm{ml}$ depending on the sample. After 1 week of preincubation, samples received either glucose (uniformly enriched in ${ }^{13} \mathrm{C}$ at a level of 5 atom\%, i.e., $5 \%$ of all $\mathrm{C}$ atoms were ${ }^{13} \mathrm{C}$; purchased from SigmaAldrich) or ammonium sulphate in aqueous solution. We optimized the solution volume added to each soil in a preliminary experiment, to ensure that samples were homogenously moistened, but not water saturated after substrate addition $(1.5 \mathrm{ml}$ for Histosols, $7.5 \mathrm{ml}$ for Podzol organic layers, and $1.0 \mathrm{ml}$ for Podzol mineral horizons). Substrates were added dropwise to the samples, and samples were shaken immediately after addition. Carbon and $\mathrm{N}$ additions varied between soils to account for differences in SOC and total soil $\mathrm{N}$ content. Each soil received an amount of $\mathrm{C}$ or $\mathrm{N}$ that corresponded to $1 \%$ of its SOC or total soil $\mathrm{N}$ content, respectively. Compared to microbial $\mathrm{C}$ in control samples after incubation, $\mathrm{C}$ addition represented $150 \pm 19, \quad 138 \pm 17$, and $291 \pm 51 \%$ of microbial $\mathrm{C}$ in the Histosol, Podzol organic layer, and Podzol mineral horizon, respectively, from Svartberget, and $432 \pm 53,185 \pm 53$, and $446 \pm 96 \%$ of microbial C in the Histosol, Podzol organic layer, and Podzol mineral horizon from Skogaryd. Control samples received neither glucose nor ammonium sulphate solution, but the equivalent volume of deionized water. Flasks were again covered with parafilm and incubated at room temperature for 1 week. Our incubation temperature thus exceeded field temperature (summer temperature at $10 \mathrm{~cm}$ depth ca. $15-20{ }^{\circ} \mathrm{C}$ in Skogaryd and $15{ }^{\circ} \mathrm{C}$ in Svartberget). Given that decades of research have demonstrated predictable increases in e.g., microbial growth, respiration and enzyme activities with temperature, and optima above $30{ }^{\circ} \mathrm{C}$ (Bárcenas-Moreno et al. 2009; Schindlbacher et al. 2015), we expect that our 


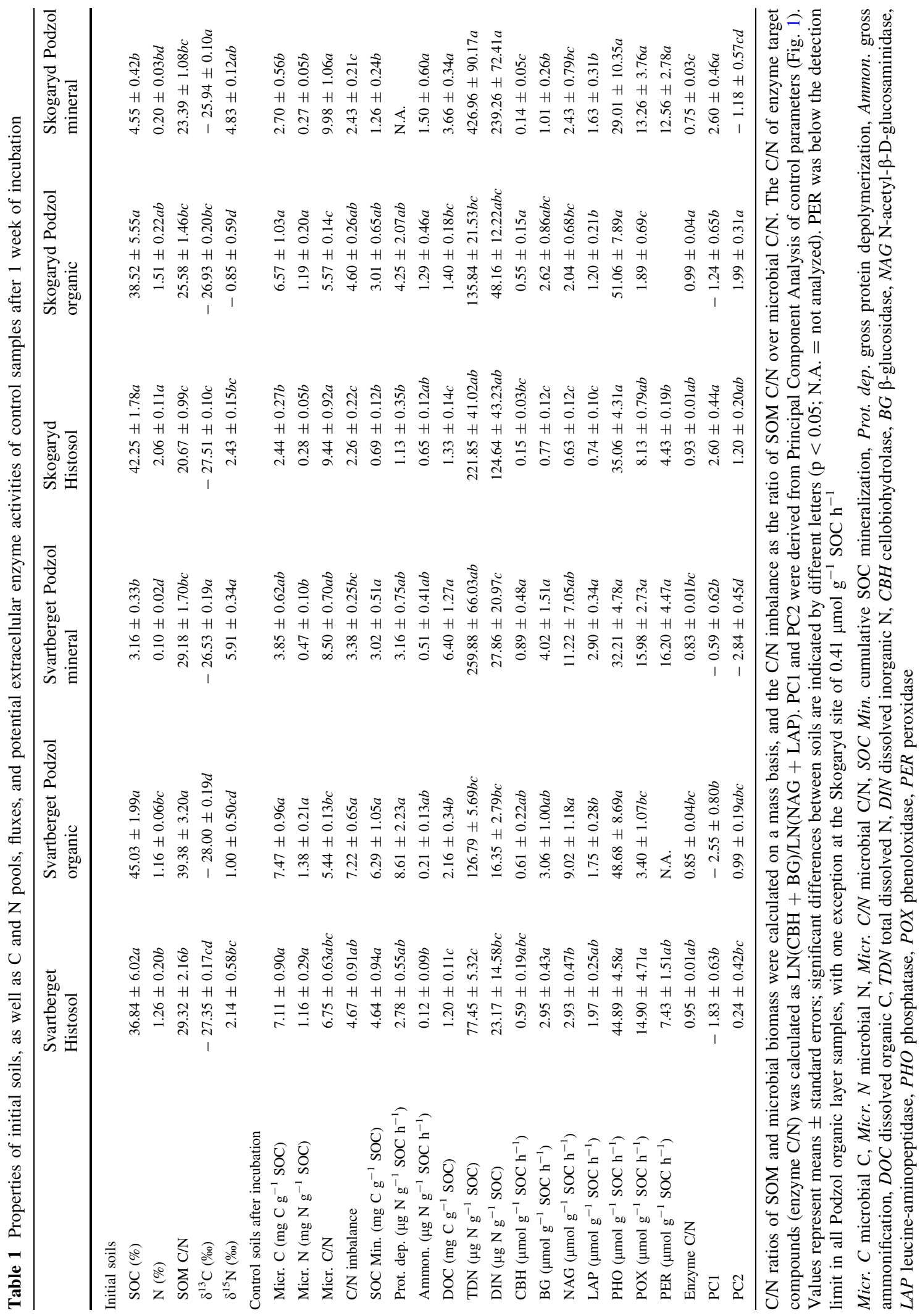


comparatively high incubation temperature affected absolute rates of $\mathrm{C}$ and $\mathrm{N}$ cycling processes, but not relative responses of these processes to changes in $\mathrm{C}$ and $\mathrm{N}$ availability.

We took the first samples of respired $\mathrm{CO}_{2} 1 \mathrm{~h}$ after substrate amendment, and then every $24 \mathrm{~h}$. For each sampling, we closed flasks with gas-tight caps with septum, evacuated and refilled four times with air of known $\mathrm{CO}_{2}$ concentration and isotopic composition (393 ppm, 1.1 atom $\%{ }^{13} \mathrm{C}$ ), and incubated samples at room temperature for $1 \mathrm{~h}$. We then mixed the headspace with a syringe, transferred aliquots into preevacuated gas vials and determined $\mathrm{CO}_{2}$ concentrations using gas chromatography (Agilent 7597A Headspace Sampler, 7890A GC System with flame ionization detector). For control and $\mathrm{C}$ addition samples, we took a second set of gas samples immediately after the first, and measured the ${ }^{13} \mathrm{C}$ content of $\mathrm{CO}_{2}$ with a trace gas-isotope ratio mass spectrometer (SerCon Automated Nitrogen Carbon Analyser ANCA-TGII and 20-20 isotope ratio mass spectrometer). We corrected respiration rates and ${ }^{13} \mathrm{C}$ contents of the respired $\mathrm{CO}_{2}$ for the initially present $\mathrm{CO}_{2}$, and then distinguished between $\mathrm{CO}_{2}$ from added glucose and from native SOC using the equations

$$
\begin{aligned}
\mathrm{C}_{\mathrm{SOC}}= & \mathrm{C}_{\text {Total }} \times\left(\text { atom } \%_{\text {Total }}-\text { atom } \%_{\mathrm{Glc}}\right) / \\
& \left(\text { atom } \%_{\mathrm{SOC}}-\text { atom } \%_{\mathrm{Glc}}\right)
\end{aligned}
$$

and

$\mathrm{C}_{\mathrm{Glc}}=\mathrm{C}_{\mathrm{Total}}-\mathrm{C}_{\mathrm{SOC}}$.

$\mathrm{C}_{\text {Total }}, \mathrm{C}_{\mathrm{SOC}}$ and $\mathrm{C}_{\mathrm{Glc}}$ represent total, SOC-derived and glucose-derived $\mathrm{CO}_{2}$, and atom $\%_{\text {Total }}$, atom $\%_{\text {SOC }}$ and atom $\%_{\mathrm{Glc}}$ the isotopic compositions (in atom $\%{ }^{13} \mathrm{C}$ ) of total $\mathrm{CO}_{2}$, SOC-derived (i.e., control) $\mathrm{CO}_{2}$, and glucose. Throughout the text, we use the term "SOC mineralization" to refer to the mineralization of native, unlabelled SOC, excluding $\mathrm{C}$ mineralized from added, ${ }^{13} \mathrm{C}$-enriched glucose. The development of SOC- and glucose-derived respiration over time is presented in Supplementary Fig. S1. After the last $\mathrm{CO}_{2}$ sampling 1 week after the start of the incubation, we harvested the soils to measure gross $\mathrm{N}$ transformation rates, extractable $\mathrm{C}$ and $\mathrm{N}$ pools, microbial biomass and potential extracellular enzyme activities. Gravimetric water content was determined in all samples, and amounted to $77.9 \pm 2.3,73.2 \pm 1.0$, and $20.9 \pm 1.1 \%$ of fresh weight (mean \pm standard error) in the Histosol, Podzol organic layer and Podzol mineral horizon, respectively, from Svartberget, and $67.8 \pm 1.0,70.2 \pm 1.3$, and $28.3 \pm 0.9 \%$ in the Histosol, Podzol organic layer and Podzol mineral horizon from Skogaryd. Differences between treatments were not significant $(\mathrm{p}>0.1)$.

\section{Gross nitrogen transformation rates}

We determined gross rates of protein depolymerization and ammonification using ${ }^{15} \mathrm{~N}$ pool dilution assays. Briefly, we labelled the product pool of the respective process (amino acids for protein depolymerization, ammonium for ammonification) with ${ }^{15} \mathrm{~N}$, and calculated the flux into the pool from the changes in concentration and isotopic composition between two timepoints (10 and $30 \mathrm{~min}$ for protein depolymerization, 4 and $24 \mathrm{~h}$ for ammonification, accounting for the different turnover times of amino acids and ammonium).

Gross protein depolymerization rates were determined following Wanek et al. (2010), as modified by Wild et al. (2013). Duplicates of fresh soil were amended with a $2 \mu \mathrm{g} \mathrm{ml}^{-1}$ solution of ${ }^{15} \mathrm{~N}$-labeled amino acids that contained $12 \%$ lysine; $9 \%$ leucine and glutamic acid; $8 \%$ aspartic acid; $6 \%$ arginine and alanine; $5 \%$ glycine, proline, glutamine, and asparagine; $4 \%$ phenylalanine, serine, valine, and threonine; $3 \%$ isoleucine, tyrosine, cysteine, and tryptophane; and $1 \%$ histidine and methionine with 96-98 atom $\%{ }^{15} \mathrm{~N}$ (Cambridge Isotope Laboratories). For Histosols and Podzol organic layers, we added $1.0 \mathrm{ml}$ of the amino acid mixture to $2 \mathrm{~g}$ fresh soil, and for Podzol mineral horizons $0.5 \mathrm{ml}$ to $4 \mathrm{~g}$ fresh soil. These additions corresponded to $10.5 \mathrm{nmol} \mathrm{N} \mathrm{g}$ fresh soil (Histosols and Podzol organic layers) and $2.6 \mathrm{nmol} \mathrm{N} \mathrm{g}{ }^{-1}$ fresh soil (Podzol mineral horizons). Samples were shaken vigorously immediately after additions to ensure a homogenous distribution of ${ }^{15} \mathrm{~N}$ amino acids, incubated for 10 or $30 \mathrm{~min}$ at room temperature, extracted with $20 \mathrm{ml}$ of a $10 \mathrm{mM} \mathrm{CaSO}_{4}$ solution containing $3.7 \%$ formaldehyde, filtered through synthetic wool and GF/C filters (Whatman), and loaded on pre-cleaned cation exchange cartridges (OnGuard II H $1 \mathrm{cc}$ cartridges, Thermo). Amino acids were eluted from the cartridges using $10 \mathrm{ml} 3 \mathrm{M} \mathrm{NH}_{3}$, amended with an internal standard mixture (norvaline, nor-leucine and para-chloro-phenylalanine, Sigma-Aldrich), and dried under reduced pressure. 
Samples were derivatized with ethyl-chloroformate (Wanek et al. 2010) and analyzed with gas chromatography-mass spectrometry (GC-MS; Thermo Trace GC and DSQ I; OV1701 column, PTV injection, $1.4 \mathrm{ml} \mathrm{min}{ }^{-1}$ helium as carrier, temperature program: $60{ }^{\circ} \mathrm{C}$ for $1.5 \mathrm{~min}$, first ramp $29^{\circ} \mathrm{C} \mathrm{min}^{-1}$ to $130^{\circ} \mathrm{C}$, second ramp $3{ }^{\circ} \mathrm{C} \min ^{-1}$ to $180{ }^{\circ} \mathrm{C}$, third ramp $15^{\circ} \mathrm{C}$ $\min ^{-1}$ to $280{ }^{\circ} \mathrm{C}, 280{ }^{\circ} \mathrm{C}$ for $5 \mathrm{~min}$ ). One set of blanks and external amino acid standards (Standard Set 1; one concentration level) was processed together with the samples throughout the entire procedure to account for background concentrations of amino acids and for incomplete recovery of amino acids from the cation exchange cartridges. A second set of external amino acid standards (Standard Set 2; eight concentration levels) was amended with the internal standards, derivatized, analyzed together with the samples, and used for calibration of alanine, glycine, leucine, proline, serine, valine, aspartate and asparagine concentrations. Asparagine and aspartate were not distinguished as formaldehyde causes the deamination of asparagine to aspartate (Wanek et al. 2010). Concentrations of individual amino acids were corrected using recovery values calculated from Standard Set 1 (alanine: $71 \%$, glycine: $73 \%$, leucine: $27 \%$, proline: $43 \%$, serine: $93 \%$, valine: $27 \%$, asparagine and aspartate: $19 \%)$. Nitrogen isotopic compositions were calculated by comparing the peak areas of amino acid fragments containing ${ }^{14} \mathrm{~N}$ or ${ }^{15} \mathrm{~N}$ (Wanek et al. 2010). Since this GC-MS based method of determining ${ }^{15} \mathrm{~N}$ isotopic values is sensitive to ${ }^{13} \mathrm{C}$ enrichment such as in the samples amended with ${ }^{13} \mathrm{C}$-labeled glucose, we conducted a parallel incubation to this treatment where we amended samples with glucose that was not enriched in ${ }^{13} \mathrm{C}$. These non-enriched glucose-amended samples were treated identically to the enriched ones and used to determine gross rates of protein depolymerization and also ammonification without interference by ${ }^{13} \mathrm{C}$.

Gross ammonification rates were measured following Kaiser et al. (2011), by amending duplicates of fresh soil with a $62.5 \mu \mathrm{M}\left({ }^{15} \mathrm{NH}_{4}\right)_{2} \mathrm{SO}_{4}$ solution (25 atom\% ${ }^{15} \mathrm{~N}$, Cambridge Isotope Laboratories; Histosols and Podzol organic layers: $1.0 \mathrm{ml}$ for $2 \mathrm{~g}$ soil; Podzol mineral horizon: $0.5 \mathrm{ml}$ for $4 \mathrm{~g}$ soil). Samples were incubated for 4 or $24 \mathrm{~h}$ at room temperature, extracted with $15 \mathrm{ml} 2 \mathrm{M} \mathrm{KCl}$, and filtered through ash-free cellulose filters (Whatman). Ammonium was isolated with acid traps (Sørensen and Jensen 1991) and analyzed with EA-IRMS (SerCon Europa EAGSL, 20-22 Stable Isotope Mass Spectrometer). All gross rates were calculated using the equations in Kirkham and Bartholomew (1954).

Extractable and microbial carbon and nitrogen pools

We determined ammonium and nitrate concentrations photometrically in $1 \mathrm{M} \mathrm{KCl}$ extracts, following Kandeler and Gerber (1988) for ammonium and Miranda et al. (2001) for nitrate. Dissolved organic $\mathrm{C}$ as well as total dissolved $\mathrm{N}$ were measured in $0.5 \mathrm{M} \mathrm{K}_{2} \mathrm{SO}_{4}$ extracts with a Shimadzu TOC-V CPH equipped with a TN unit. Since nitrification, i.e., the conversion of ammonium to nitrate, was not a focus of this study, we calculated dissolved inorganic $\mathrm{N}$ concentrations as sums of ammonium and nitrate concentrations.

Microbial $\mathrm{C}$ and $\mathrm{N}$ pools were determined with chloroform-fumigation-extraction following Kaiser et al. (2011), by fumigating soils for 2 days with ethanol-free chloroform and extracting them with $0.5 \mathrm{M} \mathrm{K}_{2} \mathrm{SO}_{4}$. Dissolved organic $\mathrm{C}$ and total dissolved $\mathrm{N}$ in extracts of fumigated and non-fumigated soils were determined as described above (Shimadzu TOC$\mathrm{V} \mathrm{CPH}$ with $\mathrm{TN}$ unit), and microbial $\mathrm{C}$ and $\mathrm{N}$ were calculated from the difference between fumigated and non-fumigated soils. We note that $\mathrm{C}$ and $\mathrm{N}$ released by chloroform-fumigation-extraction are mostly derived from microbial cytoplasm. As correction factors in the literature are highly variable (e.g., Brookes et al. 1985), we refrained from applying a correction but present values as measured. Microbial $\mathrm{C} / \mathrm{N}$ was calculated as a mass ratio. We further calculated the stoichiometric $\mathrm{C} / \mathrm{N}$ imbalance between SOM and microbial biomass following Mooshammer et al. (2014a), as the ratio of SOM C/N over microbial biomass $\mathrm{C} / \mathrm{N}$. High $\mathrm{C} / \mathrm{N}$ imbalance thus reflects $\mathrm{C}$ excess of SOM compared to the microbial biomass.

\section{Extracellular enzyme activities}

We measured potential activities of the hydrolytic enzymes cellobiohydrolase $(\mathrm{CBH}$, targeting cellulose), $\beta$-glucosidase (BG, targeting cellulose and cellobiose), $\mathrm{N}$-acetyl- $\beta$-D-glucosaminidase (NAG, targeting chitin and peptidoglycan), leucineaminopeptidase (LAP, targeting proteins and peptides), and phosphatase (PHO, targeting phosphate 
groups), as well as of the unspecific oxidative enzymes phenoloxidase (POX) and peroxidase (PER) using a combination of fluorometric and photometric assays modified after Kaiser et al. (2010) and Schindlbacher et al. (2015). Briefly, $1 \mathrm{~g}$ of soil was suspended in $100 \mathrm{ml}$ sodium acetate buffer $(100 \mathrm{mM}, \mathrm{pH} 5.5)$ and ultrasonicated. For the hydrolytic enzymes, one set of aliquots was amended with fluorescence labelled substrates in five replicates (4-methylumbelliferyl- $\beta$ D-cellobioside for cellobiosidase, 4-methylumbelliferyl- $\beta$-D-glucopyranoside for $\beta$-glucosidase, 4-methylumbelliferyl-N-acetyl- $\beta$-D-glucosaminide for $\mathrm{N}$-acetyl$\beta$-D-glucosaminidase, L-leucine-7-amido-4-methylcoumarin for leucine-aminopeptidase, 4-methylumbelliferyl-phosphate for phosphatase). A second set of aliquots was amended with different concentrations of the respective fluorescence marker (4-methylumbelliferone or 7-amido-4-methylcoumarin) to provide standards for calibration that thus accounted for possible quenching of the fluorescence signal by the soil suspension. Fluorescence of samples and standards was measured once after $140 \mathrm{~min}$ of incubation at room temperature (excitation $365 \mathrm{~nm}$, emission $450 \mathrm{~nm}$ ). To measure the oxidative enzymes phenoloxidase and peroxidase, aliquots of the soil suspensions received L-3,4-dihydroxyphenylalanine (DOPA) as substrate, and samples for peroxidase additionally $\mathrm{H}_{2} \mathrm{O}_{2}$. Samples were measured photometrically (absorbance $450 \mathrm{~nm}$ ) immediately after substrate addition and after $20 \mathrm{~h}$ of incubation at room temperature. Potential phenoloxidase activities were calculated from the change in absorbance after DOPA addition, and potential peroxidase activities from the change in absorbance after DOPA $+\mathrm{H}_{2} \mathrm{O}_{2}$ addition, subtracting the change after DOPA addition alone. We compared the microbial investment into $\mathrm{C}$ - versus $\mathrm{N}$-acquiring hydrolytic enzymes ("enzyme C/N") based on Sinsabaugh et al. (2008), by calculating the ratio of the natural logarithm of $(\mathrm{CBH}+\mathrm{BG})$ over the natural logarithm of (NAG + LAP).

\section{Statistical analyses}

All statistical analyses were performed using R 3.1.3 (R Development Core Team 2015) with the additional package GenABEL (Aulchenko et al. 2007). We present all $\mathrm{C}$ and $\mathrm{N}$ pools and fluxes normalized by unit SOC, and thus focussed not on differences in SOM quantity between soil samples, but in SOM quality (see Supplementary Tables S3 and S4 for values related to unit SOC, and Supplementary Tables S5 and S6 for values related to unit dry soil). We tested for significant differences between initial soils, and between unamended control samples using ANOVA, after log- or rank-transformation where necessary. In some cases conditions for ANOVA could not be met and we applied Mann-Whitney-U tests. We further described differences between control samples using Principal Component Analysis (PCA) of $\mathrm{C}$ and $\mathrm{N}$ pools and fluxes as well as of extracellular enzyme activities. Values for microbial $\mathrm{C}$ and $\mathrm{N}$, dissolved organic $\mathrm{C}$, total dissolved $\mathrm{N}$, dissolved inorganic $\mathrm{N}$, cumulative SOC mineralization, and potential activities of individual extracellular enzymes were normalized by unit SOC, transformed where necessary to meet the assumption of normal distribution, scaled and centered, before applying the prcomp function of the stats package in $\mathrm{R}$ 3.1.3. Peroxidase activity was below the detection limit in nine of ten samples of Podzol organic layers, and set to zero for PCA and correlations. Gross rates of protein depolymerization and ammonification are missing for some samples where amino acid or ammonium concentrations were too low for ${ }^{15} \mathrm{~N}$ determination, or where rates were below the detection limit. We therefore could not include gross $\mathrm{N}$ transformation rates in the PCA, but tested for correlation with Principal Components.

We tested for significant differences between controls and treatments using Welch's paired $t$ test in individual soils, and thus accounted for the high variability in control values and treatment responses between and even within soil categories. Data were log- or rank-transformed where necessary. Treatment effects are displayed as response ratios in tables and figures, calculated as treatment over control value for the respective parameter. We further used Spearman's rank sum correlations to test for monotonous relationships between parameters, and present Spearman's rho to describe the closeness of this relationship. Differences and correlations were considered significant at $\mathrm{p}<0.05$; for treatment effects and correlations, we also indicate effects with $\mathrm{p}<0.1$. 


\section{Results}

Carbon and nitrogen dynamics in control samples

We found high variabilities in $\mathrm{C}$ and $\mathrm{N}$ pools, fluxes and potential extracellular enzyme activities among unamended control samples, even when values were normalized by SOC content (Table 1). Microbial C and $\mathrm{N}$, cumulative SOC mineralization and gross protein depolymerization rates, as well as the activities of several hydrolytic enzymes were significantly and positively correlated with each other (Supplementary Table S1), with lower values in the Histosol and Podzol mineral horizon from Skogaryd than in the other soils (Table 1). In contrast, gross ammonification rates and concentrations of total dissolved $\mathrm{N}$ and dissolved inorganic $\mathrm{N}$ were negatively correlated with cumulative SOC mineralization, but positively with each other (Supplementary Table S1), and were highest in the Skogaryd soils (Table 1). This pattern was reflected in a Principal Component Analysis, where Principal Component 1 (PC1) separated Skogaryd Histosol and Podzol mineral horizon samples from the other soils. This separation was due to low microbial biomass, SOC mineralization, and hydrolytic enzyme activities as well as high concentrations of total dissolved $\mathrm{N}$ and dissolved inorganic $\mathrm{N}$ in the Skogaryd Histosol and Podzol mineral horizon samples (Fig. 1, Table 1). Principal Component 2 (PC2) separated Podzol mineral horizons from Podzol organic layers and Histosols irrespective of location, and this separation was driven by higher concentrations of dissolved organic $\mathrm{C}$, total dissolved $\mathrm{N}$, as well as activities of oxidative (phenoloxidase, peroxidase) and $\mathrm{N}$-acquiring hydrolytic enzymes (N-acetyl- $\beta$-Dglucosaminidase, leucine-aminopeptidase) in mineral horizons when normalized by SOC content. Gross protein depolymerization rates showed a negative correlation with PC1 (Spearman's rho $=-0.69$, $\mathrm{p}<0.01$ ), whereas gross ammonification rates were not significantly correlated with either PC.

Given that these opposing patterns were observed after normalization by SOC content, they reflect differences not in quantity, but in quality of SOM. We found that $\mathrm{PC} 1$ was negatively correlated with the $\mathrm{C} / \mathrm{N}$ ratio of SOM, as well as with the $\mathrm{C} / \mathrm{N}$ imbalance between SOM and microbial biomass (rho $=-0.67$ and $-0.84, \mathrm{p}<0.001$ in both cases). Accordingly, parameters showing a strong negative loading on PC1 (microbial $\mathrm{C}$ and $\mathrm{N}$, cumulative SOC mineralization, activities of cellobiohydrolase, $\beta$-glucosidase, $\mathrm{N}$-acetyl- $\beta$-D-glucosaminidase and leucineaminopeptidase), as well as gross protein depolymerization rates, were significantly and positively correlated with SOM C/N and C/N imbalance (rho between 0.35 and 0.88; Supplementary Table S1). Parameters with a strong positive loading on PC1 (total dissolved $\mathrm{N}$, dissolved inorganic $\mathrm{N}$ ), as well as gross ammonification rates were negatively correlated with $\mathrm{C} / \mathrm{N}$ (rho between -0.37 and -0.55$)$, and the former two also with $\mathrm{C} / \mathrm{N}$ imbalance (rho $=-0.51$ and -0.39 , respectively).

Principal Component 2 did not show a correlation with $\mathrm{C} / \mathrm{N}$ ratio or $\mathrm{C} / \mathrm{N}$ imbalance at $\mathrm{p}<0.1$, but was positively correlated with SOC and total $\mathrm{N}$ content (rho $=0.75$ and 0.73, p $<0.001$ in both cases; Supplementary Table S2), even though pools, fluxes, and enzyme activities were normalized by SOC before PCA. This correlation is in line with the separation of mineral and organic horizons along PC2.

Changes in carbon and nitrogen dynamics induced by carbon and nitrogen addition

The addition of glucose affected $\mathrm{C}$ and $\mathrm{N}$ pools and processes in all soils, but to a different extent. The Skogaryd soils showed the strongest responses, with increases in microbial $\mathrm{C}$ (but not $\mathrm{N}$ ), as well as decreases in gross ammonification rates and concentrations of total dissolved $\mathrm{N}$ and dissolved inorganic $\mathrm{N}$ (Fig. 2, Table 2). Svartberget Histosol and Podzol organic layer samples were less responsive, and showed no significant effect of glucose addition on microbial C. Gross ammonification rates increased in the Svartberget Podzol organic layer $(p<0.1)$, whereas dissolved inorganic $\mathrm{N}$ concentrations decreased in both soils $(\mathrm{p}<0.05)$. All soils showed an increase in microbial $\mathrm{C} / \mathrm{N}$ (not significant in the Skogaryd Histosol).

Although the increase in microbial $\mathrm{C}$ and the reduction in ammonification and dissolved inorganic $\mathrm{N}$ suggest that glucose addition had promoted microbial growth and $\mathrm{N}$ demand at least in the Skogaryd soils, we did not find indications for a stimulation of microbial $\mathrm{N}$ mining. The ratio of $\mathrm{C}$ - over $\mathrm{N}$-acquiring enzymes decreased in all Skogaryd soils (significant only in the Skogaryd Histosol), but this effect was rather due to a decrease in $\mathrm{C}$ - than an increase in 


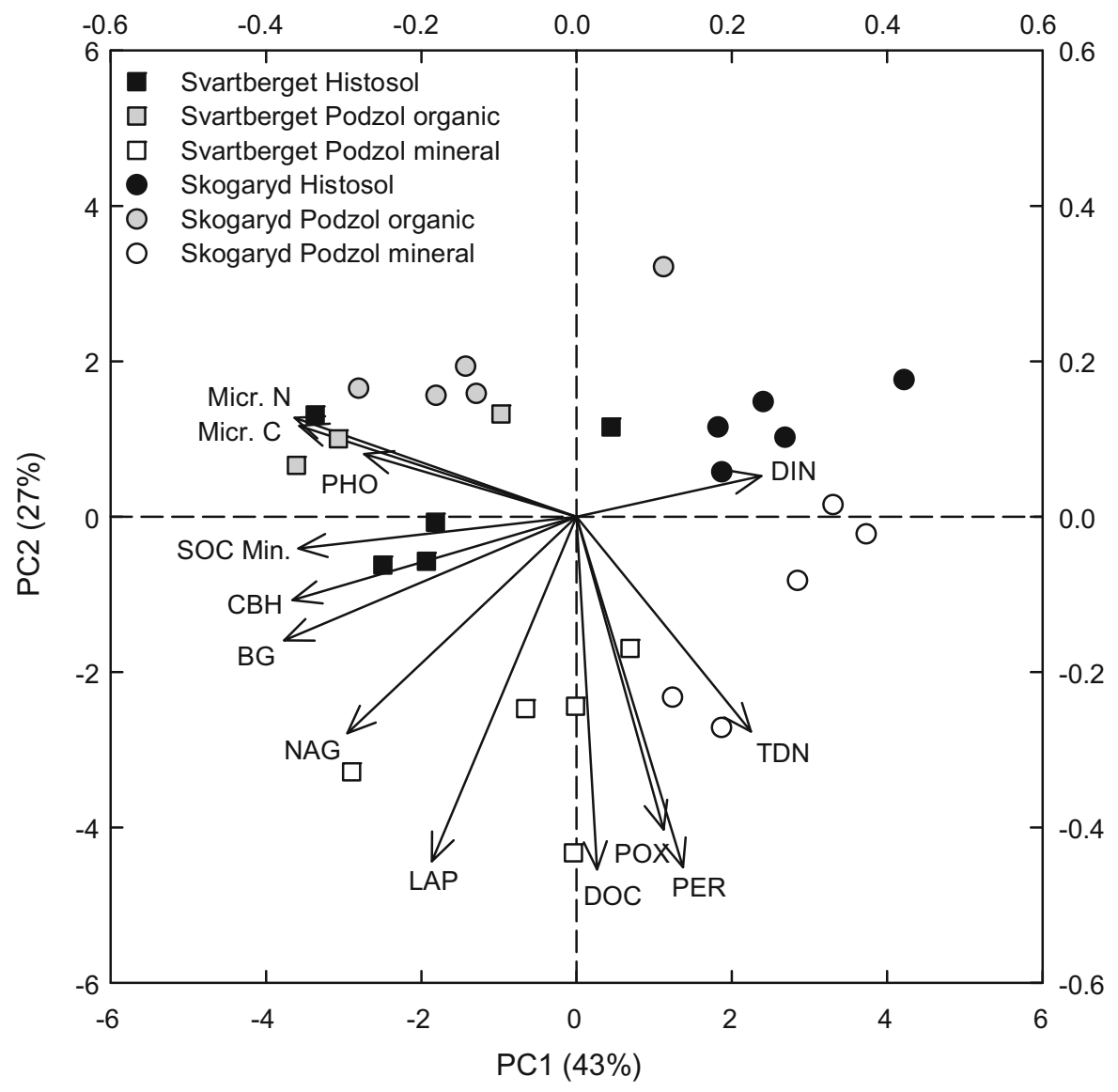

Fig. 1 Plot of Principal Components 1 and 2 from Principal Component Analysis of $\mathrm{C}$ and $\mathrm{N}$ pools, fluxes, and potential extracellular enzyme activities in control samples after 1 week of incubation (Micr. C microbial C, Micr. $N$ microbial N, SOC Min. cumulative SOC mineralization, DOC dissolved organic C, $T D N$ total dissolved $\mathrm{N}, D I N$ dissolved inorganic $\mathrm{N}, C B H$ cellobiohydrolase, $B G \beta$-glucosidase, $N A G \mathrm{~N}$-acetyl- $\beta$-D-glucosaminidase, $L A P$ leucine-aminopeptidase, $P H O$ phosphatase, $P O X$ phenoloxidase, $P E R$ peroxidase). Data were normalized by

N-targeting enzymes (Table 2). A significant increase in N-targeting enzymes was only observed in the Podzol mineral horizon from Skogaryd, where the proteolytic enzyme leucine-aminopeptidase increased by $18 \%$, the chitinolytic enzyme $\mathrm{N}$-acetyl- $\beta$-D-glucosaminidase by $47 \%$, and phosphatase, phenoloxidase and peroxidase by 95,44 and $25 \%$, respectively (Table 2). Gross protein depolymerization rates could not be measured in these samples due to low amino acid concentrations. In the other soils, we found no significant increase in enzyme activities or gross protein depolymerization rates. Cumulative SOC
SOC content, scaled and centered before analysis. Bottom and left axes apply to plotted data points, top and right axes to plotted input parameters. Gross rates of protein depolymerization and ammonification were not included due to missing data points. Protein depolymerization was negatively correlated with PC1 (Spearman's rho $=-0.69, \mathrm{p}<0.01$ ), and ammonification was not significantly correlated with either PC. Correlations between individual control parameters are shown in Supplementary Table S1

mineralization increased by $31 \%$ in the Svartberget Podzol mineral horizon $(\mathrm{p}<0.1)$ and by $46 \%$ in the Skogaryd Histosol ( $<<0.05$; Fig. 2).

In line with our hypothesis, we found that for parameters affected by $\mathrm{C}$ addition, the magnitudes of the responses depended on the initial balance between $\mathrm{C}$ and $\mathrm{N}$ availability in the soil. Strongest increases in microbial $\mathrm{C}$ and cumulative SOC mineralization, and strongest decreases in total dissolved $\mathrm{N}$ and dissolved inorganic $\mathrm{N}$ were thus observed in soils of low $\mathrm{C} / \mathrm{N}$ ratio. These relationships were indicated by negative correlations between $\mathrm{C} / \mathrm{N}$ and response ratios of 
microbial $\mathrm{C}($ rho $=-0.45, \mathrm{p}<0.05)$ and cumulative SOC mineralization ( $r h o=-0.44, \mathrm{p}<0.05$ ), and by positive correlations between $\mathrm{C} / \mathrm{N}$ and response ratios of total dissolved $\mathrm{N}$ ( rho $=0.37, \mathrm{p}<0.1)$ and dissolved inorganic $\mathrm{N}$ (rho $=0.45, \mathrm{p}<0.05$; Fig. 2, Table 2). No correlations with $\mathrm{C} / \mathrm{N}$ were found for gross rates of protein depolymerization and ammonification.

The addition of ammonium strongly increased concentrations of total dissolved $\mathrm{N}$ and dissolved inorganic $\mathrm{N}$ as well as gross ammonification rates, but had little other effect on microbial biomass and microbial processes (Table 2, Fig. 2). Cumulative SOC mineralization increased by $37 \%$ in the Svartberget Podzol mineral horizon and decreased by $11 \%$ in the Skogaryd Podzol organic layer (both $\mathrm{p}<0.1$ ). Response ratios of SOC mineralization were negatively correlated with SOC content and PC2 (rho $=-0.51$ and $-0.55, \mathrm{p}<0.01$ in both cases; data not shown), reflecting a more positive response of mineral and a more negative response of organic horizons. Although ammonium addition significantly decreased the activity of the proteolytic enzyme leucine-aminopeptidase by $34 \%$ in the Svartberget Podzol organic layer, by $20 \%$ in the Skogaryd Histosol, and by $45 \%$ in the Skogaryd Podzol organic layer (Table 2), we did not find a concomitant reduction in protein depolymerization rates. In contrast, $\mathrm{N}$ addition stimulated protein depolymerization, but this effect was not statistically significant for any of the individual soils (Fig. 2). We did not find any significant correlations between $\mathrm{C} / \mathrm{N}$ ratios of initial soils and response ratios to $\mathrm{N}$ addition at $\mathrm{p}<0.1$ (Fig. 2, Table 2).

\section{Discussion}

Our findings suggest that microorganisms in six boreal forest soils adjusted to short-term variations in $\mathrm{C}$ and $\mathrm{N}$ availability not by altering the breakdown of SOM polymers, but rather, by altering the release of excess
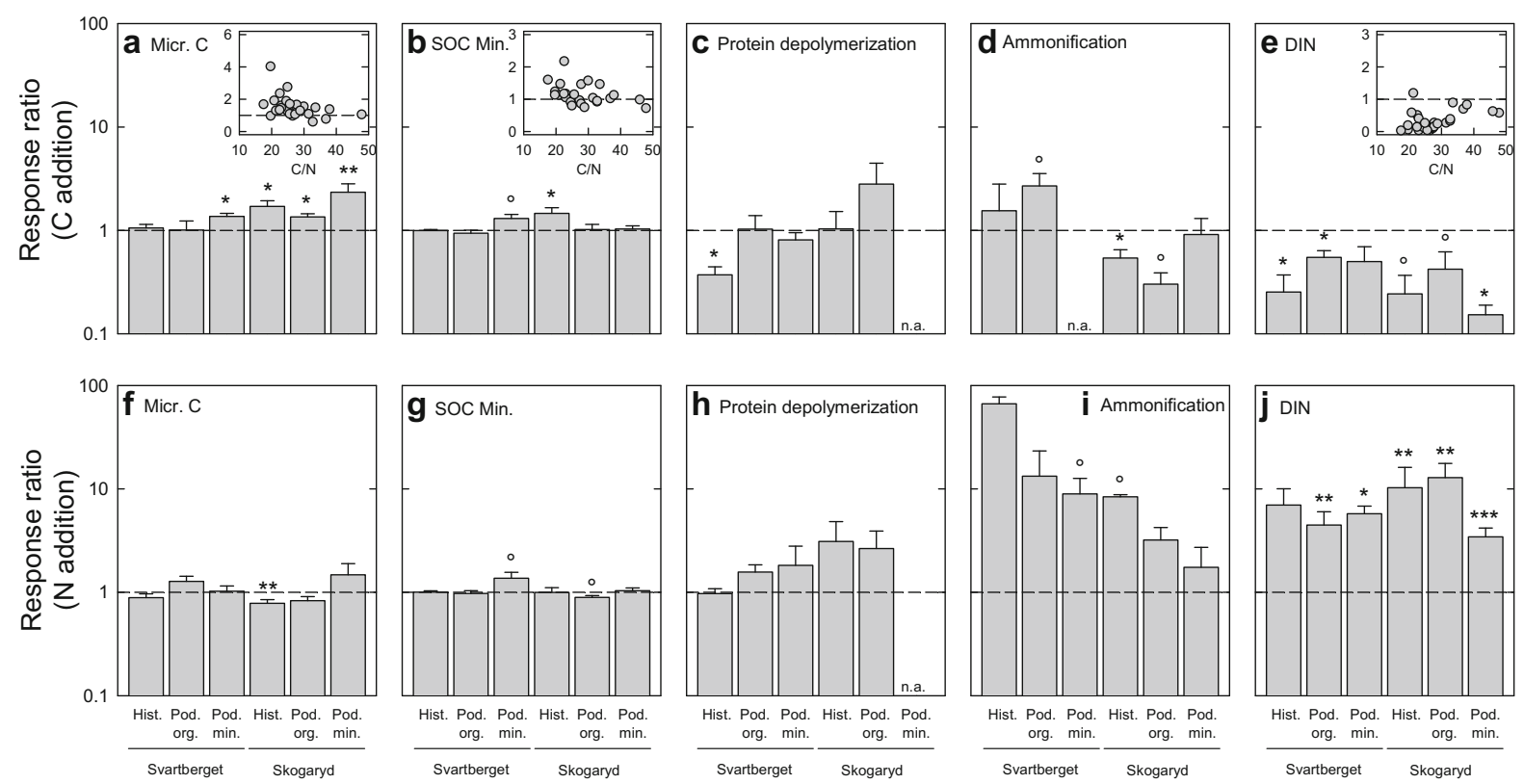

Fig. 2 Response ratios of key parameters to $\mathrm{C}(\mathbf{a}-\mathbf{e})$ or $\mathrm{N}(\mathbf{f}-$ j) addition (Micr. C microbial C, SOC Min. cumulative SOC mineralization, DIN dissolved inorganic $\mathrm{N}$ ) in six boreal forest soils (Hist. Histosol, Pod. org. Podzol organic layer, Pod. min. Podzol mineral B horizon). Response ratios were calculated as treatment over control values, and significant differences between treatment and control values are indicated (Welch's paired $t$ tests between control and treatment; *** $\mathrm{p}<0.001$; $\left.{ }^{*} \mathrm{p}<0.01 ; * \mathrm{p}<0.05 ;{ }^{\circ} \mathrm{p}<0.1\right)$. Note the logarithmic scaling. Response ratios of microbial C, SOC mineralization and dissolved inorganic $\mathrm{N}$ to $\mathrm{C}$ addition were significantly correlated with $\mathrm{C} / \mathrm{N}$ ratios of initial soils (plotted in inserts; Spearman's rho $=-0.45$ for microbial $\mathrm{C}$, rho $=-0.44$ for SOC mineralization, and rho $=0.45$ for dissolved inorganic $\mathrm{N}$, $\mathrm{p}<0.05$ in all cases). See Table 2 for response ratios and correlations of other measured parameters 
Table 2 Response ratios to $\mathrm{C}$ and $\mathrm{N}$ addition after 1 week of incubation

\begin{tabular}{|c|c|c|c|c|c|c|c|}
\hline & $\begin{array}{l}\text { Svartberget } \\
\text { Histosol }\end{array}$ & $\begin{array}{l}\text { Svartberget } \\
\text { Podzol organic }\end{array}$ & $\begin{array}{l}\text { Svartberget } \\
\text { Podzol mineral }\end{array}$ & $\begin{array}{l}\text { Skogaryd } \\
\text { Histosol }\end{array}$ & $\begin{array}{l}\text { Skogaryd } \\
\text { Podzol organic }\end{array}$ & $\begin{array}{l}\text { Skogaryd } \\
\text { Podzol mineral }\end{array}$ & $\begin{array}{l}\text { Corr. } \\
\text { with } \\
\text { C/N }\end{array}$ \\
\hline \multicolumn{8}{|l|}{$\mathrm{C}$ addition } \\
\hline Microbial N & $0.81 \pm 0.13$ & $0.78 \pm 0.17$ & $0.89 \pm 0.07$ & $0.85 \pm 0.12$ & $0.83 \pm 0.05^{*}$ & $1.09 \pm 0.14$ & N.S. \\
\hline Microbial $\mathrm{C} / \mathrm{N}$ & $1.45 \pm 0.23^{\circ}$ & $1.31 \pm 0.03 * *$ & $1.55 \pm 0.03 * * *$ & $2.33 \pm 0.67^{\circ}$ & $1.63 \pm 0.06^{* *}$ & $2.22 \pm 0.21^{*}$ & N.S. \\
\hline DOC & $1.03 \pm 0.06$ & $1.00 \pm 0.16$ & $1.13 \pm 0.07$ & $1.77 \pm 0.43$ & $0.89 \pm 0.05$ & $1.17 \pm 0.16$ & N.A. \\
\hline TDN & $0.98 \pm 0.04$ & $0.94 \pm 0.14$ & $1.11 \pm 0.12$ & $0.61 \pm 0.18^{\circ}$ & $0.69 \pm 0.13$ & $0.50 \pm 0.11^{\circ}$ & $0.37^{\circ}$ \\
\hline $\mathrm{CBH}$ & $1.26 \pm 0.37$ & $1.60 \pm 0.55$ & $0.76 \pm 0.11^{\circ}$ & $0.75 \pm 0.08^{\circ}$ & $0.93 \pm 0.21$ & $1.19 \pm 0.32$ & N.S. \\
\hline BG & $1.00 \pm 0.10$ & $1.63 \pm 0.58$ & $0.96 \pm 0.08$ & $0.80 \pm 0.06^{*}$ & $0.82 \pm 0.15$ & $1.00 \pm 0.09$ & $0.40^{*}$ \\
\hline NAG & $0.97 \pm 0.05$ & $1.05 \pm 0.11$ & $0.90 \pm 0.07$ & $0.90 \pm 0.09$ & $0.95 \pm 0.14$ & $1.47 \pm 0.27^{\circ}$ & N.S. \\
\hline LAP & $0.96 \pm 0.06$ & $0.93 \pm 0.05$ & $1.05 \pm 0.03$ & $1.02 \pm 0.10$ & $0.91 \pm 0.06$ & $1.18 \pm 0.04 * *$ & N.S. \\
\hline PHO & $0.98 \pm 0.05$ & $1.06 \pm 0.10$ & $0.81 \pm 0.10$ & $1.12 \pm 0.12$ & $0.95 \pm 0.04$ & $1.95 \pm 0.35^{*}$ & N.S. \\
\hline POX & $1.27 \pm 0.29$ & $1.10 \pm 0.19$ & $0.92 \pm 0.02 *$ & $0.78 \pm 0.20$ & $1.03 \pm 0.55$ & $1.44 \pm 0.17^{\circ}$ & N.S. \\
\hline PER & $1.24 \pm 0.20$ & N.A. & $0.92 \pm 0.09$ & $0.85 \pm 0.22$ & N.A. & $1.25 \pm 0.10^{*}$ & N.S. \\
\hline Enzyme C/N & $1.00 \pm 0.01$ & $1.04 \pm 0.04$ & $1.00 \pm 0.02$ & $0.96 \pm 0.01^{*}$ & $0.98 \pm 0.04$ & $0.95 \pm 0.03$ & $0.47 * *$ \\
\hline \multicolumn{8}{|l|}{$\mathrm{N}$ addition } \\
\hline Microbial N & $0.99 \pm 0.13$ & $0.97 \pm 0.11$ & $1.14 \pm 0.08$ & $1.09 \pm 0.11$ & $0.99 \pm 0.07$ & $1.12 \pm 0.22$ & N.S. \\
\hline Microbial C/N & $0.95 \pm 0.10$ & $1.36 \pm 0.28$ & $0.90 \pm 0.08$ & $0.73 \pm 0.05^{* *}$ & $0.84 \pm 0.03^{* *}$ & $1.27 \pm 0.09^{*}$ & N.S. \\
\hline DOC & $0.94 \pm 0.10$ & $0.91 \pm 0.07$ & $1.04 \pm 0.05$ & $1.08 \pm 0.05$ & $0.90 \pm 0.05$ & $0.95 \pm 0.07$ & N.S. \\
\hline TDN & $2.20 \pm 0.44^{\circ}$ & $1.71 \pm 0.29^{\circ}$ & $1.72 \pm 0.17 *$ & $3.35 \pm 0.51 * * *$ & $4.31 \pm 0.77 * *$ & $1.98 \pm 0.20^{* * *}$ & N.A. \\
\hline $\mathrm{CBH}$ & $1.53 \pm 0.33$ & $1.65 \pm 0.69$ & $1.00 \pm 0.21$ & $0.75 \pm 0.05^{*}$ & $1.02 \pm 0.11$ & $1.68 \pm 0.33$ & N.S. \\
\hline BG & $1.09 \pm 0.11$ & $1.39 \pm 0.38$ & $0.92 \pm 0.08$ & $0.87 \pm 0.16$ & $0.88 \pm 0.19$ & $1.07 \pm 0.14$ & N.S. \\
\hline NAG & $1.02 \pm 0.11$ & $1.02 \pm 0.10$ & $1.04 \pm 0.17$ & $0.88 \pm 0.07$ & $1.01 \pm 0.12$ & $1.48 \pm 0.47$ & N.S. \\
\hline LAP & $0.97 \pm 0.13$ & $0.66 \pm 0.04 *$ & $1.03 \pm 0.05$ & $0.80 \pm 0.04 * *$ & $0.55 \pm 0.03 * * *$ & $1.08 \pm 0.07$ & N.S. \\
\hline PHO & $1.13 \pm 0.08$ & $1.09 \pm 0.15$ & $0.88 \pm 0.19$ & $0.89 \pm 0.03^{\circ}$ & $0.93 \pm 0.04$ & $1.46 \pm 0.23^{\circ}$ & N.S. \\
\hline POX & $0.97 \pm 0.05$ & $1.13 \pm 0.27$ & $0.94 \pm 0.07$ & $0.85 \pm 0.23$ & $1.32 \pm 0.68$ & $1.09 \pm 0.10$ & N.S. \\
\hline PER & $0.97 \pm 0.06$ & N.A. & $0.93 \pm 0.12$ & $0.77 \pm 0.19$ & N.A. & $1.18 \pm 0.11$ & N.S. \\
\hline Enzyme C/N & $1.02 \pm 0.01$ & $1.04 \pm 0.04$ & $0.99 \pm 0.02$ & $0.99 \pm 0.02$ & $1.01 \pm 0.04$ & $0.98 \pm 0.03$ & N.S. \\
\hline
\end{tabular}

The $\mathrm{C} / \mathrm{N}$ ratio of the microbial biomass was calculated on a mass basis, and the $\mathrm{C} / \mathrm{N}$ of enzyme target compounds (enzyme $\mathrm{C} / \mathrm{N}$ ) as $\mathrm{LN}(\mathrm{CBH}+\mathrm{BG}) / \mathrm{LN}(\mathrm{NAG}+\mathrm{LAP})$. Response ratios were calculated as treatment over control values, means \pm standard errors are presented. Significant differences between treatment and control values are indicated (Welch's paired $t$ tests between control and treatment). The right column shows results of Spearman's correlations between response ratios across all soils and $\mathrm{C} / \mathrm{N}$ ratios of SOM; Spearman's rho for correlations significant at $\mathrm{p}<0.1$ are shown $\left(* * * \mathrm{p}<0.001 ; * * \mathrm{p}<0.01 ; * \mathrm{p}<0.05\right.$; $^{\circ} \mathrm{p}<0.1 ; N . S$. not significant, N.A. not analyzed). Correlations of DOC for $\mathrm{C}$ addition, and of TDN for $\mathrm{N}$ addition were not tested as soils received different amounts of $\mathrm{C}$ or $\mathrm{N}$ to account for variability in initial SOC and total N contents. See Fig. 2 for response ratios of selected key parameters (microbial C, SOC mineralization, gross protein depolymerization, ammonification, and dissolved inorganic $\mathrm{N}$ concentrations)

$D O C$ dissolved organic $\mathrm{C}, T D N$ total dissolved N, $C B H$ cellobiohydrolase, $B G$-glucosidase, $N A G$ N-acetyl- $\beta$-D-glucosaminidase, $L A P$ leucine-aminopeptidase, $P H O$ phosphatase, $P O X$ phenoloxidase, $P E R$ peroxidase

$\mathrm{C}$ and $\mathrm{N}$ via mineralization to $\mathrm{CO}_{2}$ or ammonium. The predominance of this adaptation mechanism was supported both for the natural gradient in $\mathrm{C}$ and $\mathrm{N}$ availability across our soils, and for short-term experimental increases in $\mathrm{C}$ or $\mathrm{N}$ availability. Our findings thus contrast previous suggestions that increased soil $\mathrm{C}$ availability, e.g., due to increased plant $\mathrm{C}$ input, stimulates the microbial synthesis of enzymes targeting $\mathrm{N}$-rich SOM polymers and thus accelerates the mobilization of available $\mathrm{N}$.

We found that microbial $\mathrm{C}$ and $\mathrm{N}$ transformation processes in unamended soils, as well as their responses to short-term $\mathrm{C}$ input, depended on properties of the initial SOM that we qualified using SOM $\mathrm{C} / \mathrm{N}$ ratios. The observed dependency on SOM C/N ratios is in line with a threshold elemental ratio (TER) 
where microorganisms switch between $\mathrm{C}$ and $\mathrm{N}$ limitation (e.g., Manzoni et al. 2012; Moorhead et al. 2012; Mooshammer et al. 2014a, b; Sinsabaugh et al. 2013). We found that soils of high $\mathrm{C} / \mathrm{N}$ ratio showed high SOC mineralization, but low ammonification rates, as well as low concentrations of dissolved inorganic N (normalized by SOC content; Supplementary Table S1), pointing at an excess of $\mathrm{C}$, but a shortage of $\mathrm{N}$ for microorganisms. These findings are in line with stoichiometric theory which predicts high $\mathrm{C}$ mineralization and low ammonification at high $\mathrm{C} / \mathrm{N}$, and vice versa (e.g., Mooshammer et al. 2014b). However, $\mathrm{C} / \mathrm{N}$ ratios were also positively correlated with microbial biomass, activities of $\mathrm{C}$ - and $\mathrm{N}$-acquiring hydrolytic enzymes, as well as protein depolymerization rates. Our data thus suggest a second, overlapping mechanism that links SOM C/N ratios to SOM decomposition. As $\mathrm{C} / \mathrm{N}$ ratios decrease during SOM decomposition, high $\mathrm{C} / \mathrm{N}$ ratios coincide with SOM that is predominantly plant-derived, still rather poorly decomposed, and not protected by association with soil minerals (Rumpel and Kögel-Knabner 2011; von Lützow et al. 2006). Such easily degradable SOM can support a large and highly active microbial community, further facilitating positive correlations of $\mathrm{C} / \mathrm{N}$ with SOC mineralization, but also with microbial biomass, enzyme activities, and protein depolymerization, as observed in our study. Taken together, we suggest that $\mathrm{C} / \mathrm{N}$ ratios served as a proxy for relative $\mathrm{C}$ availability across our samples, and reflect both SOM stoichiometry (i.e., $\mathrm{C}$ versus $\mathrm{N}$ availability) and, indirectly, SOM degradability. In soils of high $\mathrm{C} / \mathrm{N}, \mathrm{C}$ availability exceeded microbial $\mathrm{C}$ demand also without $\mathrm{C}$ addition, as indicated by high $\mathrm{C} / \mathrm{N}$ imbalances even when considering the additional $\mathrm{C}$ demand for maintenance respiration (Sinsabaugh et al. 2013). In line with our hypothesis, these soils did not show a strong response to short-term $\mathrm{C}$ input (Fig. 2, Table 2).

Soils of low $\mathrm{C} / \mathrm{N}$ ratio, in contrast, showed low SOC mineralization, but high ammonification rates, and high concentrations of dissolved inorganic N (Supplementary Table $\mathrm{S} 1$ ), suggesting that microorganisms experienced an excess of $\mathrm{N}$, and a shortage of $\mathrm{C}$. We found that these $\mathrm{N}$-rich soils responded most strongly to short-term $\mathrm{C}$ addition, and showed increases in microbial $\mathrm{C}$ and SOC mineralization (Fig. 2). Given the short incubation time, part of the increase in SOC mineralization might not have been caused by accelerated SOM decomposition ("real priming"), but by the replacement of non-labelled, SOC-derived microbial $\mathrm{C}$ by labelled, glucose-derived C ("apparent priming"; Blagodatskaya and Kuzyakov 2008). In any case, the positive priming effect was not connected to a stimulation of microbial $\mathrm{N}$ mining, as indicated by minor effects on gross protein depolymerization rates and $\mathrm{N}$-acquiring enzyme activities. We instead observed a reduction in gross ammonification rates and dissolved inorganic $\mathrm{N}$ concentrations (Fig. 2). Although these findings support a stimulation of microbial growth and microbial $\mathrm{N}$ demand by $\mathrm{C}$ addition in soils of low $\mathrm{C}$ availability, they also suggest that microorganisms had no need to increase the release of available $\mathrm{N}$ from SOM to meet their increased $\mathrm{N}$ demand, but rather reduced the initially high release of excess $\mathrm{N}$ by ammonification. Such changes in internal microbial $\mathrm{C}$ and $\mathrm{N}$ metabolism leave SOM breakdown rates unaffected, and have rarely been taken into account in the context of ecosystem $\mathrm{C}$ and $\mathrm{N}$ storage. A number of studies, however, have recently highlighted the importance of microbial $\mathrm{C}$ and $\mathrm{N}$ use efficiencies for ecosystem $\mathrm{C}$ and $\mathrm{N}$ cycling. Low $\mathrm{C}$ and $\mathrm{N}$ use efficiencies (i.e., high mineralization compared to uptake rates) thus correspond to large ecosystem $\mathrm{C}$ and $\mathrm{N}$ losses (e.g., as $\mathrm{CO}_{2}$, $\mathrm{N}_{2} \mathrm{O}$ or nitrate), whereas high $\mathrm{C}$ and $\mathrm{N}$ use efficiencies promote the build-up of microbial biomass, which is the main precursor for SOM (Manzoni et al. 2012; Mooshammer et al. 2014a; Sinsabaugh et al. 2013). Such microbially derived organic matter can account for more than $50 \%$ of SOM, and for more than $80 \%$ of total soil N (Simpson et al. 2007). We consequently argue that changes in the microbial allocation of $\mathrm{C}$ and $\mathrm{N}$ to mineralization, such as observed in our 1-week incubation study, can significantly affect the ecosystem $\mathrm{C}$ and $\mathrm{N}$ balance, by altering not the breakdown, but the formation of SOM polymers (see also Schmidt et al. 2011). In our soils, the observed decrease in gross ammonification rates and dissolved inorganic $\mathrm{N}$ concentrations with $\mathrm{C}$ addition corresponds to a decrease in soil $\mathrm{N}$ availability that reduces the potential for plant $\mathrm{N}$ uptake, but also for soil $\mathrm{N}$ losses, e.g., by nitrate leaching and denitrification.

In contrast to short-term $\mathrm{C}$ addition that hardly affected extracellular enzyme activities, short-term $\mathrm{N}$ addition significantly reduced potential activities of the proteolytic enzyme leucine-aminopeptidase in three of the six studied soils (Table 2), but not actual 
gross protein depolymerization rates. Such a decoupling between leucine-aminopeptidase activity and gross protein depolymerization rates has been previously observed in a litter decomposition study (Wanek et al. 2010), and suggests that either leucineaminopeptidase is not representative for the multitude of proteolytic enzymes active in soils (Vranova et al. 2013), or that protein depolymerization is not limited by enzyme activity, but by substrate availability, e.g., due to protection of soil proteins (Knicker 2011). While the analysis of potential extracellular enzyme activities provides valuable information about the microbial investment into enzymes targeting different compounds, it cannot substitute the measurement of actual gross transformation rates.

Although we did not find support for a stimulation of microbial $\mathrm{N}$ mining by increased $\mathrm{C}$ availability over the course of 1 week, we emphasize that our findings do not rule out that plants can promote microbial $\mathrm{N}$ mining and at least partly compensate for the $\mathrm{N}$ they take up from the soil. Support for a positive effect of plants on $\mathrm{N}$ mining is provided by a range of studies that show higher activities of N-targeting enzymes, gross ammonification rates and soil $\mathrm{N}$ losses in rhizosphere than in non-rhizosphere soil (Brzostek et al. 2013; Holz et al. 2016; Kieloaho et al. 2016; Koranda et al. 2011; Weintraub et al. 2007; Zhu et al. 2014), a stimulation of N-targeting enzymes by artificial root exudates (Meier et al. 2017), and positive correlations between rates of root exudation, SOC and (gross or net) $\mathrm{N}$ mineralization in experiments with intact plants (Bengtson et al. 2012; Yin et al. 2013, 2014). The strongest support for a stimulation of microbial $\mathrm{N}$ mining by increased plant $\mathrm{C}$ input comes from experiments where plants were exposed to elevated $\mathrm{CO}_{2}$ concentrations. These studies report an increase in fine root biomass and turnover, plant-soil $\mathrm{C}$ allocation, activities of $\mathrm{N}$-targeting enzymes and tree $\mathrm{N}$ uptake with elevated $\mathrm{CO}_{2}$ and suggest that a stimulation of microbial $\mathrm{N}$ mining by increased plantsoil $\mathrm{C}$ transfer can help to sustain high plant productivity in a future climate (Drake et al. 2011; Phillips et al. 2011, 2012; Zak et al. 2011). Such a feedback mechanism could be crucial for the $\mathrm{C}$ balance of terrestrial ecosystems. A recent modelling study found that ecosystem $\mathrm{C}$ storage depended on soil $\mathrm{N}$ and $\mathrm{P}$ availability, and emphasized that an increase in net primary production, as predicted with rising atmospheric $\mathrm{CO}_{2}$ concentrations, cannot be realized unless there is a concurrent increase in the release of available $\mathrm{N}$ from SOM (Wieder et al. 2015). However, while experiments on living plants realistically describe plant effects on soil $\mathrm{N}$ dynamics under natural conditions, they hardly permit the dissection of individual underlying mechanisms as required for predicting plant effects across ecosystems and global change scenarios.

By isolating effects of $\mathrm{C}$ and $\mathrm{N}$ availability on soil processes, we show that effects of living roots on soil $\mathrm{N}$ dynamics do not simply result from increased soil $\mathrm{C}$ availability, but might require specific environmental conditions or a specific form of $\mathrm{C}$ input. We here discuss four potential requirements: (1) Nitrogen mining might take place only after long exposure to increased $\mathrm{C}$ availability. While root hairs have a life span of a few days (Kuzyakov and Xu 2013) that is comparable to our 1-week incubation, root litter decomposition might result in a longer lasting enhancement of $\mathrm{C}$ availability, and might induce different adaptation mechanisms in the soil microbial community. Similarly, N mining might take place only after repeated exposure to increased $\mathrm{C}$ availability. Nevertheless, a previous study found weaker priming when the same amount of $\mathrm{C}$ was added in small, repeated doses than in one single dose (Qiao et al. 2014), (2) it has been suggested that $\mathrm{N}$ mining is induced only by organic compounds in polymeric form that might promote a microbial community specialized on the breakdown of SOM polymers, whereas monomeric compounds such as glucose might promote a copiotrophic microbial community of limited depolymerization capacity (Fontaine et al. 2003). Also in this case, microbial N mining would be connected to root litter production rather than to root exudation, which is dominated by monomeric compounds such as glucose (Jones et al. 2009), (3) a stimulation of microbial $\mathrm{N}$ mining might also be restricted to the input of compounds that contain not only $\mathrm{C}$, but also $\mathrm{N}$. Although $\mathrm{N}$ addition often reduces SOC mineralization (which has been interpreted as a reduction in microbial $\mathrm{N}$ mining; Craine et al. 2007; Phillips et al. 2011), some studies show a stronger stimulation of SOC mineralization when both $\mathrm{C}$ and $\mathrm{N}$ are supplied (Chen et al. 2014; Wild et al. 2016), possibly since the added $\mathrm{N}$ can be used for enzyme synthesis (Allison et al. 2009; Drake et al. 2013). However, a stimulation of enzyme synthesis by $\mathrm{N}$ was not observed in this study (Table 2), and (4) finally, 
microbial $\mathrm{N}$ mining might depend on the association of plants with mycorrhizal fungi, an effect that we would have underestimated in our laboratory experiment. Ectomycorrhiza - the dominant mycorrhiza in boreal forests-have been linked to the release of available N from SOM polymers (Lindahl et al. 2007; Talbot et al. 2013), and to increased $\mathrm{N}$ mining under elevated $\mathrm{CO}_{2}$ (Drake et al. 2011; Terrer et al. 2016). Microbial $\mathrm{N}$ mining might thus depend not on plantsoil $\mathrm{C}$ allocation in general, but specifically on the allocation of $\mathrm{C}$ to certain mycorrhiza. However, recent studies in boreal forests suggest that a high transfer of $\mathrm{C}$ from plants to ectomycorrhiza can also reduce plant $\mathrm{N}$ uptake as ectomycorrhiza keep a larger proportion of the available $\mathrm{N}$ for themselves (Hasselquist et al. 2016; Näsholm et al. 2013). Our laboratory experiment showed a similar stimulation of $\mathrm{N}$ sequestration by $\mathrm{C}$ input in non-symbiotic soil microorganisms and suggests that increased $\mathrm{C}$ availability can at least in the short term also reduce $\mathrm{N}$ availability for plants.

\section{Conclusions}

We provide insights into the regulation of protein depolymerization under changing $\mathrm{C}$ and $\mathrm{N}$ availability during a time frame of 1 week. In contrast to our hypothesis, we found that non-symbiotic soil microorganisms adjusted to a short-term increase in $\mathrm{C}$ availability not by accelerating the mobilization of $\mathrm{N}$ from SOM polymers such as proteins, but rather by using the already available $\mathrm{N}$ more efficiently. Considering that (1) $\mathrm{C}$ effects on microbial processes are typically restricted to soils of initially low $\mathrm{C}$ availability (e.g., Bengtson et al. 2012; Wild et al. 2016), and that (2) these soils are typically characterized by an excess of $\mathrm{N}$, and by low $\mathrm{N}$ use efficiency (e.g., Mooshammer et al. 2014a; Wild et al. 2015; see also Supplementary Table S1), an increase in microbial N use efficiency might be a common adjustment to enhanced soil $\mathrm{C}$ availability and microbial $\mathrm{N}$ demand. Although our findings do not rule out that an increase in plant-soil $\mathrm{C}$ allocation, such as expected with rising atmospheric $\mathrm{CO}_{2}$ concentrations and temperatures, can promote the release of available $\mathrm{N}$ from SOM polymers, they show that such an effect can be counteracted at least in the short term by an increase in microbial $\mathrm{N}$ use efficiency, reducing soil $\mathrm{N}$ availability and aggravating plant $\mathrm{N}$ limitation, but also mitigating soil $\mathrm{N}$ losses, e.g., by nitrate leaching and denitrification.

Acknowledgements We thank Leif Klemedtsson and Mats Nilsson for providing soil samples, and Katja van Nieuland and Stijn Vandevoorde for support with IRMS analysis. This study was funded by the Swedish Research Council Formas (Project Numbers 229-2011-716 and 2012-1541) and the Strategic Area Biodiversity and Ecosystem Services in a Changing Climate (BECC; www.becc.lu.se). This work was made possible by the Swedish Infrastructure for Ecosystem Science (SITES), in this case by the Swedish University of Agricultural Sciences, Svartberget Experimental Forest Research Station, and the University of Gothenburg, Skogaryd Research Catchment.

Open Access This article is distributed under the terms of the Creative Commons Attribution 4.0 International License (http:// creativecommons.org/licenses/by/4.0/), which permits unrestricted use, distribution, and reproduction in any medium, provided you give appropriate credit to the original author(s) and the source, provide a link to the Creative Commons license, and indicate if changes were made.

\section{References}

Allison SD, LeBauer DS, Ofrecio MR, Reyes R, Ta A-M, Tran TM (2009) Low levels of nitrogen addition stimulate decomposition by boreal forest fungi. Soil Biol Biochem 41:293-302. doi:10.1016/j.soilbio.2008.10.032

Aulchenko Y, Ripke S, Isaacs A, Duijn C (2007) GenABEL: an $\mathrm{R}$ library for genome-wide association analysis. Bioinformatics 23:1294-1296. doi:10.1093/bioinformatics/btm108

Bárcenas-Moreno $\mathrm{G}$, Gómez-Brandón $\mathrm{M}$, Rousk $\mathrm{J}$, Bååth $\mathrm{E}$ (2009) Adaptation of soil microbial communities to temperature: comparison of fungi and bacteria in a laboratory experiment. Glob Chang Biol 15:2950-2957. doi:10.1111/ j.1365-2486.2009.01882.x

Bengtson P, Barker J, Grayston S (2012) Evidence of a strong coupling between root exudation, $\mathrm{C}$ and $\mathrm{N}$ availability, and stimulated SOM decomposition caused by rhizosphere priming effects. Ecol Evol 2:1843-1852. doi:10.1002/ ece 3.311

Blagodatskaya E, Kuzyakov Y (2008) Mechanisms of real and apparent priming effects and their dependence on soil microbial biomass and community structure: critical review. Biol Fertil Soils 45:115-131. doi:10.1007/s00374008-0334-y

Brookes PC, Landman A, Pruden G, Jenkinson DS (1985) Chloroform fumigation and the release of soil nitrogen: a rapid direct extraction method to measure microbial biomass nitrogen in soil. Soil Biol Biochem 17:837-842. doi:10.1016/0038-0717(85)90144-0

Brzostek ER, Greco A, Drake JE, Finzi AC (2013) Root carbon inputs to the rhizosphere stimulate extracellular enzyme activity and increase nitrogen availability in temperate forest soils. Biogeochemistry 115:65-76. doi:10.1007/ s10533-012-9818-9 
Chen R, Senbayram M, Blagodatsky S, Myachina O, Dittert K, Lin X, Blagodatskaya E, Kuzyakov Y (2014) Soil C and N availability determine the priming effect: microbial $\mathrm{N}$ mining and stoichiometric decomposition theories. Glob Chang Biol 20:2356-2367. doi:10.1111/gcb.12475

Craine J, Morrow C, Fierer N (2007) Microbial nitrogen limitation increases decomposition. Ecology 88:2105-2113. doi:10.1890/06-1847.1

Drake JE, Gallet-Budynek A, Hofmockel KS, Bernhardt ES, Billings SA, Jackson RB, Johnsen KS, Lichter J, McCarthy HR, McCormack ML, Moore DJ, Oren R, Palmroth S, Phillips R, Pippen JS, Pritchard SG, Treseder KK, Schlesinger WH, DeLucia EH, Finzi AC (2011) Increases in the flux of carbon belowground stimulate nitrogen uptake and sustain the long term enhancement of forest productivity under elevated $\mathrm{CO}_{2}$. Ecol Lett 14:349-357. doi:10. 1111/j.1461-0248.2011.01593.x

Drake JE, Darby BA, Giasson M-A, Kramer MA, Phillips RP, Finzi AC (2013) Stoichiometry constrains microbial response to root exudation-insights from a model and a field experiment in a temperate forest. Biogeosciences 10:821-838. doi:10.5194/bg-10-821-2013

Fan Z, Jastrow JD, Liang C, Matamala R, Miller RM (2013) Priming effects in boreal black spruce forest soils: quantitative evaluation and sensitivity analysis. PLoS ONE 8:e77880. doi:10.1371/journal.pone.0077880

Fontaine S, Mariotti A, Abbadie L (2003) The priming effect of organic matter: a question of microbial competition? Soil Biol Biochem 35:837-843. doi:10.1016/S00380717(03)00123-8

Garcia-Pausas J, Paterson E (2011) Microbial community abundance and structure are determinants of soil organic matter mineralisation in the presence of labile carbon. Soil Biol Biochem 43:1705-1713. doi:10.1016/j.soilbio.2011. 04.016

Geisseler D, Horwath WR (2009) Relationship between carbon and nitrogen availability and extracellular enzyme activities in soil. Pedobiologia 53:87-98. doi:10.1016/j.pedobi. 2009.06.002

Hartley IP, Garnett MH, Sommerkorn M, Hopkins DW, Fletcher BJ, Sloan VL, Phoenix GP, Wookey PA (2012) A potential loss of carbon associated with greater plant growth in the European Arctic. Nat Clim Chang 2:875-879. doi:10.1038/ nclimate 1575

Hasselquist NJ, Metcalfe DB, Inselsbacher E, Stangl Z, Oren R, Näsholm T, Högberg P (2016) Greater carbon allocation to mycorrhizal fungi reduces tree nitrogen uptake in a boreal forest. Ecology 97:1012-1022. doi:10.1890/15-1222

Holz M, Aurangojeb M, Kasimir Å, Boeckx P, Kuzyakob Y, Klemedtsson L, Rütting T (2016) Gross nitrogen dynamics in the mycorrhizosphere of an organic forest soil. Ecosystems 19:284-295. doi:10.1007/s10021-015-9931-4

Inselsbacher E, Näsholm T (2012) The below-ground perspective of forest plants: soil provides mainly organic nitrogen for plants and mycorrhizal fungi. New Phytol 195:329-334. doi:10.1111/j.1469-8137.2012.04169.x

IUSS Working Group WRB (2007) World Reference Base for Soil Resources 2006, first update 2007. World Soil Resources Reports No. 103. FAO, Rome

Jan MT, Roberts P, Tonheim SK, Jones DL (2009) Protein breakdown represents a major bottleneck in nitrogen cycling in grassland soils. Soil Biol Biochem 41:2272-2282. doi:10.1016/j.soilbio.2009.08.013

Jones D, Nguyen C, Finlay R (2009) Carbon flow in the rhizosphere: carbon trading at the soil root interface. Plant Soil 321:5-33. doi:10.1007/s11104-009-9925-0

Kaiser C, Koranda M, Kitzler B, Fuchslueger L, Schnecker J, Schweiger P, Rasche F, Zechmeister-Boltenstern S, Sessitsch A, Richter A (2010) Belowground carbon allocation by trees drives seasonal patterns of extracellular enzyme activities by altering microbial community composition in a beech forest soil. New Phytol 187:843-858. doi:10.1111/ j.1469-8137.2010.03321.x

Kaiser C, Fuchslueger L, Koranda M, Gorfer M, Stange C, Kitzler B, Rasche F, Strauss J, Sessitsch A, ZechmeisterBoltenstern S, Richter A (2011) Plants control the seasonal dynamics of microbial $\mathrm{N}$ cycling in a beech forest soil by belowground $\mathrm{C}$ allocation. Ecology 92:1036-1051. doi:10. 1890/10-1011.1

Kandeler E, Gerber H (1988) Short-term assay of soil urease activity using colorimetric determination of ammonium. Biol Fertil Soils 6:68-72. doi:10.1007/BF00257924

Kieloaho A-J, Pihlatie M, Dominguez Carrasco M, Kanerva S, Parshintsev J, Riekkola M-L, Pumpanen J, Heinonsalo J (2016) Stimulation of soil organic nitrogen pool: the effect of plant and soil organic matter degrading enzymes. Soil Biol Biochem 96:97-106. doi:10.1016/j.soilbio.2016.01. 013

Kirkham D, Bartholomew WV (1954) Equations for following nutrient transformations in soil, utilizing tracer data. Soil Sci Soc Am J 18:33-34. doi:10.2136/sssaj1954. 03615995001800010009x

Knicker H (2011) Soil organic N-an under-rated player for C sequestration in soils? Soil Biol Biochem 43:1118-1129. doi:10.1016/j.soilbio.2011.02.020

Koranda M, Schnecker J, Kaiser C, Fuchslueger L, Kitzler B, Stange C, Sessitsch A, Zechmeister-Boltenstern S, Richter A (2011) Microbial processes and community composition in the rhizosphere of European beech-the influence of plant C exudates. Soil Biol Biochem 43:551-558. doi:10. 1016/j.soilbio.2010.11.022

Koranda M, Kaiser C, Fuchslueger L, Kitzler B, Sessitsch A, Zechmeister-Boltenstern S, Richter A (2013) Seasonal variation in functional properties of the microbial communities in beech forest soil. Soil Biol Biochem 60:95-104. doi:10.1016/j.soilbio.2013.01.025

Kuzyakov Y, Blagodatskaya E (2015) Microbial hotspots and hot moments in soil: concept and review. Soil Biol Biochem 83:184-199. doi:10.1016/j.soilbio.2015.01.025

Kuzyakov Y, Xu X (2013) Competition between roots and microorganisms for nitrogen: mechanisms and ecological relevance. New Phytol 198:656-669. doi:10.1111/nph.12235

Kuzyakov Y, Friedel J, Stahr K (2000) Review of mechanisms and quantification of priming effects. Soil Biol Biochem 32:1485-1498. doi:10.1016/S0038-0717(00)00084-5

Landi L, Valori F, Ascher J, Renella G, Falchini L, Nannipieri P (2006) Root exudate effects on the bacterial communities, $\mathrm{CO}_{2}$ evolution, nitrogen transformations and ATP content of rhizosphere and bulk soils. Soil Biol Biochem 38:509-516. doi:10.1016/j.soilbio.2005.05.021

Laudon H, Taberman I, Ågren A, Futter M, Ottosson-Löfvenius M, Bishop K (2013) The Krycklan Catchment Study-a 
flagship infrastructure for hydrology, biogeochemistry, and climate research in the boreal landscape. Water Resour Res 49:7154-7158. doi:10.1002/wrcr.20520

LeBauer DS, Treseder KK (2008) Nitrogen limitation of net primary productivity in terrestrial ecosystems is globally distributed. Ecology 89:371-379. doi:10.1890/06-2057.1

Lindahl B, Ihrmark K, Boberg J, Trumbore S, Högberg P, Stenlid J, Finlay R (2007) Spatial separation of litter decomposition and mycorrhizal nitrogen uptake in a boreal forest. New Phytol 173:611-620. doi:10.1111/j.14698137.2006.01936.x

Manzoni S, Taylor P, Richter A, Porporato A, Ågren G (2012) Environmental and stoichiometric controls on microbial carbon-use efficiency in soils. New Phytol 196:79-91. doi:10.1111/j.1469-8137.2012.04225.x

Meier IC, Finzi AC, Phillips RP (2017) Root exudates increase $\mathrm{N}$ availability by stimulating microbial turnover of fastcycling N pools. Soil Biol Biochem 106:119-128. doi:10. 1016/j.soilbio.2016.12.004

Miranda K, Espey M, Wink D (2001) A rapid, simple spectrophotometric method for simultaneous detection of nitrate and nitrite. Nitric Oxide 5:62-71. doi:10.1006/niox. 2000.0319

Moorhead DL, Lashermes G, Sinsabaugh R (2012) A theoretical model of $\mathrm{C}$ - and $\mathrm{N}$-acquiring exoenzyme activities, which balances microbial demands during decomposition. Soil Biol Biochem 53:133-141. doi:10.1016/j.soilbio.2012.05. 011

Mooshammer M, Wanek W, Hämmerle I, Fuchslueger L, Hofhansl F, Knoltsch A, Schnecker J, Takriti M, Watzka M, Wild B, Keiblinger K, Zechmeister-Boltenstern S, Richter A (2014a) Adjustment of microbial nitrogen use efficiency to carbon: nitrogen imbalances regulates soil nitrogen cycling. Nat Commun 5:3694. doi:10.1038/ ncomms 4694

Mooshammer M, Wanek W, Zechmeister-Boltenstern S, Richter A (2014b) Stoichiometric imbalances between terrestrial decomposer communities and their resources: mechanisms and implications of microbial adaptations to their resources. Front Microbiol 5:22. doi:10.3389/fmicb. 2014.00022

Murphy CJ, Baggs EM, Morley N, Wall DP, Paterson E (2015) Rhizosphere priming can promote mobilisation of N-rich compounds from soil organic matter. Soil Biol Biochem 81:236-243. doi:10.1016/j.soilbio.2014.11.027

Näsholm T, Högberg P, Franklin O, Metcalfe D, Keel S, Campbell C, Hurry V, Linder S, Högberg M (2013) Are ectomycorrhizal fungi alleviating or aggravating nitrogen limitation of tree growth in boreal forests? New Phytol 198:214-221. doi:10.1111/nph.12139

Phillips RP, Finzi AC, Bernhardt ES (2011) Enhanced root exudation induces microbial feedbacks to $\mathrm{N}$ cycling in a pine forest under long term $\mathrm{CO}_{2}$ fumigation. Ecol Lett 14:187-194. doi:10.1111/j.1461-0248.2010.01570

Phillips RP, Meier IC, Bernhardt ES, Grandy AS, Wicking K, Finzi AC (2012) Roots and fungi accelerate carbon and nitrogen cycling in forests exposed to elevated $\mathrm{CO}_{2}$. Ecol Lett 15:1042-1049. doi:10.1111/j.1461-0248.2012.01827. $\mathrm{X}$

Qiao N, Schaefer D, Blagodatskaya E, Zou X, Xu X, Kuzyakov $\mathrm{Y}$ (2014) Labile carbon retention compensates for $\mathrm{CO}_{2}$ released by priming in forest soils. Glob Chang Biol 20:1943-1954. doi:10.1111/gcb.12458

R Development Core Team (2015) A language and environment for statistical computing. R Foundation for Statistical Computing, Vienna

Read DJ, Perez-Moreno J (2003) Mycorrhizas and nutrient cycling in ecosystems - a journey towards relevance? New Phytol 157:475-492. doi:10.1046/j.1469-8137.2003. 00704.x

Rovira AD (1969) Plant root exudates. Bot Rev 35:35-57. doi:10.1007/BF02859887

Rumpel C, Kögel-Knabner I (2011) Deep soil organic matter a key but poorly understood component of terrestrial C cycle. Plant Soil 338:143-158. doi:10.1007/s11104-010-0391-5

Schimel J, Bennett J (2004) Nitrogen mineralization: challenges of a changing paradigm. Ecology 85:591-602. doi:10. 1890/03-8002

Schindlbacher A, Schnecker J, Takriti M, Borken W, Wanek W (2015) Microbial physiology and soil $\mathrm{CO}_{2}$ efflux after 9 years of soil warming in a temperate forest-no indications for thermal adaptations. Glob Chang Biol 21:4265-4277. doi:10.1111/gcb.12996

Schmidt M, Torn M, Abiven S, Dittmar T, Guggenberger G, Janssens I, Kleber M, Kögel-Knabner I, Lehmann J, Manning D, Nannipieri P, Rasse D, Weiner S, Trumbore S (2011) Persistence of soil organic matter as an ecosystem property. Nature 478:49-56. doi:10.1038/nature 10386

Schulten H-R, Schnitzer M (1998) The chemistry of soil organic nitrogen: a review. Biol Fert Soils 26:1-15. doi:10.1007/ s003740050335

Simpson AJ, Simpson MJ, Smith E, Kelleher BP (2007) Microbially derived inputs to soil organic matter: are current estimates too low? Environ Sci Technol 41:8070-8076. doi:10.1021/es071217x

Sinsabaugh RL, Lauber CL, Weintraub MN, Ahmed B, Allison SD, Crenshaw C, Contosta AR, Cusack D, Frey S, Gallo ME, Gartner TB, Hobbie SE, Holland K, Keeler BL, Powers JS, Stursova M, Takacs-Vesbach C, Waldrop MP, Wallenstein MD, Zak DR, Zeglin L (2008) Stoichiometry of soil enzyme activity at global scale. Ecol Lett 11:1252-1264. doi:10.1111/j.1461-0248.2008.01245.x

Sinsabaugh RL, Manzoni S, Moorhead DL, Richter A (2013) Carbon use efficiency of microbial communities: stoichiometry, methodology and modelling. Ecol Lett 16:930-939. doi:10.1111/ele.12113

Sørensen P, Jensen ES (1991) Sequential diffusion of ammonium and nitrate from soil extracts to a polytetrafluoroethylene trap for ${ }^{15} \mathrm{~N}$ determination. Anal Chim Acta 252:201-203. doi:10.1016/0003-2670(91)87215-S

Spohn M, Chodak M (2015) Microbial respiration per unit biomass increases with carbon-to-nutrient ratios in forest soils. Soil Biol Biochem 81:128-133. doi:10.1016/j. soilbio.2014.11.008

Talbot JM, Bruns TD, Smith DP, Branco S, Glassman SI, Erlandson S, Vilgalys R, Peay KG (2013) Independent roles of ectomycorrhizal and saprotrophic communities in soil organic matter decomposition. Soil Biol Biochem 57:282-291. doi:10.1016/j.soilbio.2012.10.004

Terrer C, Vicca S, Hungate BA, Phillips RP, Prentice IC (2016) Mycorrhizal association as a primary control of the $\mathrm{CO}_{2}$ 
fertilization effect. Science 353:72-74. doi:10.1126/ science.aaf 4610

Vitousek P, Howarth R (1991) Nitrogen limitation on land and in the sea: how can it occur? Biogeochemistry 13:87-115. doi:10.1007/BF00002772

von Lützow M, Kögel-Knabner I, Ekschmitt K, Matzner E, Guggenberger G, Marschner B, Flessa H (2006) Stabilization of organic matter in temperate soils: mechanisms and their relevance under different soil conditions-a review. Eur J Soil Sci 57:426-445. doi:10.1111/j.13652389.2006.00809.x

Vranova V, Rejsek K, Formanek P (2013) Proteolytic activity in soil: a review. Appl Soil Ecol 70:23-32. doi:10.1016/j. apsoil.2013.04.003

Wanek W, Mooshammer M, Blöchl A, Hanreich A, Richter A (2010) Determination of gross rates of amino acid production and immobilization in decomposing leaf litter by a novel ${ }^{15} \mathrm{~N}$ isotope pool dilution technique. Soil Biol Biochem 42:1293-1302. doi:10.1016/j.soilbio.2010.04.001

Weintraub MN, Scott-Denton LE, Schmidt SK, Monson RK (2007) The effects of tree rhizodeposition on soil exoenzyme activity, dissolved organic carbon, and nutrient availability in a subalpine forest ecosystem. Oecologia 154:327-338. doi:10.1007/s00442-007-0804-1

Wieder WR, Cleveland CC, Smith WK, Todd-Brown K (2015) Future productivity and carbon storage limited by terrestrial nutrient availability. Nat Geosci 8:441-444. doi:10. 1038/ngeo2413

Wild B, Schnecker J, Bárta J, Čapek P, Guggenberger G, Hofhansl F, Kaiser C, Lashchinsky N, Mikutta R, Mooshammer M, Šantrůčková H, Shibistova O, Urich T, Zimov S, Richter A (2013) Nitrogen dynamics in turbic cryosols from Siberia and Greenland. Soil Biol Biochem 67:85-93. doi:10.1016/j.soilbio.2013.08.004

Wild B, Schnecker J, Alves RJE, Barsukov P, Bárta J, Čapek P, Gentsch N, Gittel A, Guggenberger G, Lashchinskiy N, Mikutta R, Rusalimova O, Santrůčková H, Shibistova O, Urich T, Watzka M, Zrazhevskaya G, Richter A (2014)
Input of easily available organic $\mathrm{C}$ and $\mathrm{N}$ stimulates microbial decomposition of organic matter in arctic permafrost soil. Soil Biol Biochem 75:143-151. doi:10.1016/ j.soilbio.2014.04.014

Wild B, Schnecker J, Knoltsch A, Takriti M, Mooshammer M, Gentsch N, Mikutta R, Alves RJE, Gittel A, Lashchinskiy N, Richter A (2015) Microbial nitrogen dynamics in organic and mineral soil horizons along a latitudinal transect in western Siberia. Glob Biogeochem Cycle 29:567-582. doi:10.1002/2015GB005084

Wild B, Gentsch N, Čapek P, Diáková K, Alves RJE, Bárta J, Gittel A, Hugelius G, Knoltsch A, Kuhry P, Lashchinskiy N, Mikutta R, Palmtag J, Schleper C, Schnecker J, Shibistova O, Takriti M, Torsvik VL, Urich T, Watzka M, Šantrǔčková H, Guggenberger G, Richter A (2016) Plantderived compounds stimulate the decomposition of organic matter in permafrost soils. Sci Rep 6:25607. doi:10.1038/ srep25607

Yin H, Li Y, Xiao J, Xu Z, Cheng X, Liu Q (2013) Enhanced root exudation stimulates soil nitrogen transformations in a subalpine coniferous forest under experimental warming. Glob Chang Biol 19:2158-2167. doi:10.1111/gcb.12161

Yin H, Wheeler E, Phillips RP (2014) Root-induced changes in nutrient cycling in forests depend on exudation rates. Soil Biol Biochem 78:213-221. doi:10.1016/j.soilbio.2014.07. 022

Yin H, Phillips RP, Liang R, Xu Z, Liu Q (2016) Resource stoichiometry mediates soil $\mathrm{C}$ loss and nutrient transformations in forest soils. Appl Soil Ecol 108:248-257

Zak DR, Pregitzer KS, Kubiske ME, Burton AJ (2011) Forest productivity under elevated $\mathrm{CO}_{2}$ and $\mathrm{O}_{3}$ : positive feedbacks to soil $\mathrm{N}$ cycling sustain decade-long net primary productivity enhancement by $\mathrm{CO}_{2}$. Ecol Lett 14:1220-1226. doi:10.1111/j.1461-0248.2011.01692.x

Zhu B, Gutknecht J, Herman D, Keck D, Firestone M, Cheng W (2014) Rhizosphere priming effects on soil carbon and nitrogen mineralization. Soil Biol Biochem 76:183-192. doi:10.1016/j.soilbio.2014.04.033 